Portland State University

PDXScholar

Spring 7-6-2018

\title{
Anarchism on the Willamette: the Firebrand \\ Newspaper and the Origins of a Culturally American Anarchist Movement, 1895-1898
}

Alecia Jay Giombolini

Portland State University

Follow this and additional works at: https://pdxscholar.library.pdx.edu/open_access_etds

Part of the United States History Commons

Let us know how access to this document benefits you.

\section{Recommended Citation}

Giombolini, Alecia Jay, "Anarchism on the Willamette: the Firebrand Newspaper and the Origins of a Culturally American Anarchist Movement, 1895-1898" (2018). Dissertations and Theses. Paper 4471. https://doi.org/10.15760/etd.6355

This Thesis is brought to you for free and open access. It has been accepted for inclusion in Dissertations and Theses by an authorized administrator of PDXScholar. Please contact us if we can make this document more accessible: pdxscholar@pdx.edu. 
Anarchism on the Willamette:

The Firebrand Newspaper and the Origins of

a Culturally American Anarchist Movement, 1895-1898

by

Alecia Jay Giombolini

A thesis submitted in partial fulfillment of the requirements for the degree of

Master of Arts

in

History

Thesis Committee:

Joseph Bohling, Chair

Katrine Barber

Catherine McNeur

Cristine Paschild

Portland State University

2018 
(C) 2018 Alecia Jay Giombolini 


\begin{abstract}
The Firebrand was an anarchist communist newspaper that was printed in Portland, Oregon from January 1895 to September 1897. The newspaper was a central catalyst behind the formation of the culturally American anarchist movement, a movement whose vital role in shaping radicalism in the United States during the Progressive Era has largely been ignored by historians. The central argument of this thesis is that the Firebrand publishers' experiences in Gilded Age Portland shaped the content and the format of the newspaper and led to the development of a new, uniquely American expression of anarchism.
\end{abstract}

Anarchism was developed in response to the great transformations of the nineteenth century and the anxieties of a society that was being entirely restructured as industrialization and urbanization took hold across the globe. The anarchism of the Firebrand was a regional response to these same changes, an expression of radical discontent at the way in which life in Portland and the Pacific Northwest was rapidly changing. According to the Firebranders, the region had transformed from a place of economic opportunity and political freedom into a region driven by economic and political exploitation. Thus, the newspaper developed a uniquely western American perspective and expressed a formation of anarchist communism that was steeped in the history and culture of the United States. The newspaper was just as influenced by centuries of American libertarian activism as it was by outright anarchist philosophy. As a result, the newspaper frequently included articles about free love and women's rights, issues outside of the typical purview of anarchist communist political philosophy. This 
Americanized expression of anarchist communism allowed the newspaper to expand beyond the movement's core urban, immigrant audience and attract culturally American, English-speaking radicals to the cause.

In the Fall of 1897, after two years and eight months in publication, three of the Firebrand publishers were arrested for the crime of sending obscene materials through the mail. The Firebrand's frank discussions of sexuality, women's rights, and free love offended the local censor and gave law enforcement an excuse to prosecute Portland's anarchists. The ensuing trial would result in the newspaper's closure. Nonetheless, a new intellectual movement had been established, and though the movement would remain small, it would play a disproportionately large role in shaping radical American politics and culture for the next two decades. 


\section{Acknowledgments}

I would first like to thank my thesis advisor, Professor Joseph Bohling, for sticking with me through this project's many iterations. Without his encouragement, feedback, and general enthusiasm for historical study, this project would not have been possible. I am also deeply grateful to Professor Katy Barber for her considerable support during my time at Portland State University. Whether it was by inviting me to join a weekly writing group, supporting my interest in local history, or providing incredibly in-

depth notes to my many thesis drafts, Professor Barber stood by me and pushed me to do my best work. I would also like to acknowledge my thesis committee and thank them for their invaluable feedback during this process.

I am very lucky to have such a wonderful family who were there for me every step of the way. I am especially thankful to my parents for the countless ways in which they have stood by me and my work over the years. Finally, this thesis would never have been completed without the support of my amazing wife Meagan. Thank you for all the love, guidance, and copy editing. 
Table of Contents

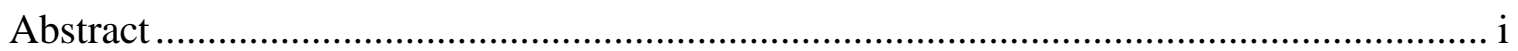

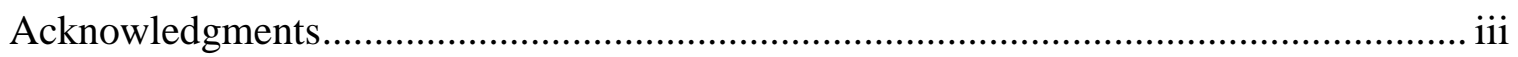

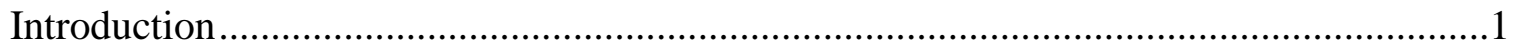

Chapter I: Radicalism in Portland and the Origins of the Firebrand ............................19

Chapter II: Anarchism and the Myth of the West....................................................55

Chapter III: The Growth of the Firebrand and the Development of a Culturally

American Anarchist Voice.................................................................................. 77

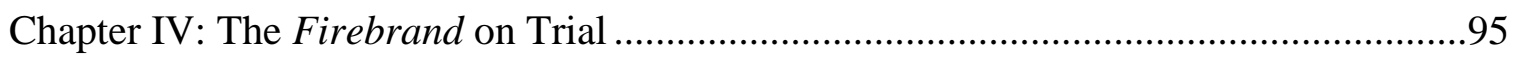

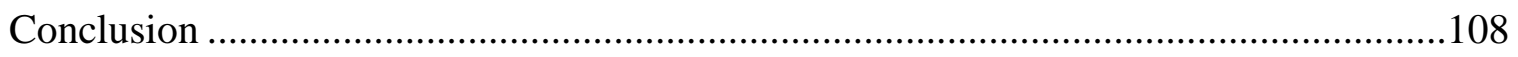

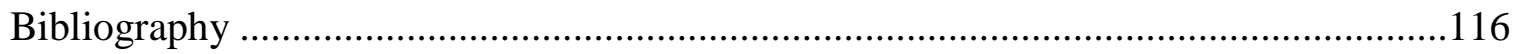




\section{Introduction}

On September 6, 1901, Leon Czolgosz, a self-declared anarchist, shot President William McKinley twice in the chest at point blank range with a concealed pistol. A week later, the president died of his wounds, and the American anarchist movement was thrust into the forefront of the nation's consciousness. The shooting occurred at the PanAmerican Exposition, a World's Fair held in Buffalo, New York. The Exposition was intended to be a celebration of Pan-American solidarity but following the United States' victory during the Spanish-American War, the event had become a symbolic celebration of the United States' ascendency in the western hemisphere. ${ }^{1}$ Under the leadership of President McKinley, the United States had turned away from its century-old isolationist polices by defeating Spain and seizing its former colonies. The United States now positioned itself as the major imperial power in the western hemisphere, signaling to the old powers of Europe that America was now a contender on the geopolitical stage. The Pan-American Exposition became a direct representation of the nation's new role in the world, utilizing design to reflect the nation's European heritage as well as its new, modern American identity. The exposition juxtaposed Renaissance and Spanish Mission architecture with a sense of American modernity, by using thousands of electric Edison

\footnotetext{
${ }^{1}$ For a detailed account of the Exposition and the assassination of William McKinley see, Scott Miller, The President and the Assassin: McKinley, Terror, and Empire at the Dawn of The American Century (New York: Random House Trade Paperbacks, 2013). I also referred to the New York Times, the Chicago Tribune, and the Oregonian from September 6, 1901 to September 16, 1901 to piece together this narrative and have highlighted particularly important articles from these sources in the following footnotes.
} 
light bulbs to illuminate the exposition's elegant domed structures, gondola filled canals, and numerous classical sculptures. ${ }^{2}$

The shooting occurred at the Temple of Music, a massive, golden domed concert hall, ornately decorated in the Italian Renaissance style, where the President was holding a reception and shaking hands with fairgoers. Czolgosz approached the president, pistol concealed beneath a cloth in his outstretched right hand. As President McKinley began to instinctively reach out his own hand, the assassin fired his weapon. Czolgosz was immediately tackled to the ground by nearby members of the crowd, who then began to beat the assailant, their attacks only halted at the request of the wounded, but surprisingly lucid president. The assassin was arrested and the president rushed to a nearby hospital. ${ }^{3}$ After undergoing surgery, the president's physicians seemed certain that he would recover from the wounds. So confident were they that Vice President Theodore Roosevelt, who had rushed to Buffalo as soon as he heard of the attack, returned to the Adirondacks where he had been vacationing with his family. A week later, the President's wounds unexpectedly became gangrenous and his condition deteriorated quickly. McKinley died on September 14, 1901. ${ }^{4}$ Upon hearing the news, Roosevelt returned to Buffalo and was sworn in as the $26^{\text {th }}$ president of the United States. Thus began one of the most impactful presidencies in American history.

\footnotetext{
${ }^{2}$ For an in-depth discussion of the way in which architecture and design was used to express American ascendency in the western hemisphere at the Pan-American Exposition see, "Pan-American Exposition of 1901," University at Buffalo Libraries, accessed February 15, 2018, https://library.buffalo.edu/panam/exposition/art/formula.html\#note3

3 Miller, The President and the Assassin, 300-303; "President Shot at Buffalo Fair," New York Times, September 7, 1901; Chicago Sunday Tribune, September 8, 1901, 1-4.

${ }^{4}$ Miller, The President and the Assassin, 312-320; "Great Hope for the President," New York Times, September 9, 1901, 1; "President M’Kinley[sic] is Dead," Morning Oregonian, September 14, $1901,1$.
} 
Roosevelt's presidency was a watershed moment in American history that overshadowed the shocking death of his predecessor. The assassination of William McKinley, and the devastating psychological impact it had on the American public, has therefore not received the level of scholarly attention that it deserves. But a quick analysis of contemporary newspaper accounts following the assassination reveals how devastated the American public was following the death of their president and just how angry they were at the assassin and the anarchist movement from which he came.

McKinley had been a popular, well-liked president and Americans of all stripes were looking for an explanation for the man's shocking assassination. In the days following the shooting, newspapers across the country held the entire American anarchist movement responsible for the President's death. ${ }^{5}$ Newspapers published innumerable attacks against anarchism, frequently depicting the ideology as an un-American, inherently violent, foreign importation. Raw, editorialized emotion drove the response to the crime. Most contributors used large portions of their limited space to condemn anarchism and call for its eradication in the United States, often advocating the use of violence to achieve this goal. One commentator in the New York Times used a story about a Methodist worship service to laud Americans' violent reactions to the President's assassination:

Ten thousand Methodists, assembled in the auditorium for divine worship this morning applauded the Rev. Dr. T. De Witt Talmage of Washington when he said, his voice trembling with emotion: 'I wish that Buffalo policeman who seized the pistol of the scoundrel who shot our beloved president had taken the butt end of the weapon and dashed the man's brains out on the spot!' It was a patriotic service from beginning to end. ${ }^{6}$

6 "The Rev. Dr. Talmage Scores the Assassin," New York Times, September 9, 1901, 2. 
Moreover, writers often insisted the crime was an act of foreign or immigrant terror. In the New York Times, a local police magistrate and a self-proclaimed expert on anarchism, argued that the solution to the United States' anarchist problem was to "pass a law barring all immigration coming from the South of Europe, from which our anarchists come, for ten years." The magistrate argued that "American citizens rarely become Anarchists, and when they do it is because they are densely ignorant and have imbibed the malign teachings of Anarchists of foreign birth." Hundreds of like-minded opinion pieces were published in newspapers across the United States, all of which ignored the complicated reality of American anarchism in which American libertarian traditions, which stretch back to Thomas Paine and Thomas Jefferson, were just as influential as European anarchist philosophy.

In Portland, the Oregonian newspaper printed dozens of editorials written by both national and local leaders regarding the assassination in the weeks that followed the crime. In an article titled "Bliss Says Clean Out the Anarchists," Secretary of the Interior, Cornelius N. Bliss sought to find an answer to the question of, "Why should anyone wish him [McKinley] ill," arguing that "the answer is that we have within our borders a tribe of foreign devils who glory in calling themselves anarchists. Their creed is to destroy all rulers no matter whether they are good or bad." ${ }^{\prime 8}$ A local Portland contributor pushed this argument even further, arguing that the crime was committed by the foreign anarchist element, as those of "Teutonic" origins were incapable of such a crime: "Assassination is

\footnotetext{
7 "Plan to Stamp Out Anarchy," New York Times, September 10, 1901, 2.

8 "Bliss Says Clean Out the Anarchists," Sunday Oregonian, September 8, 1903, 3.
} 
a crime of peculiar abhorrence to men of Teutonic or northern stock and speech ... The idea and act which this abominable word represents are so foreign to our race that we had to go to another language for the word to call it by." 9 Very few in Portland seemed to realize that just a few years earlier a small anarchist newspaper called the Firebrand had been published in their own city and that one of its publishers had been arrested in Chicago in connection with the crime.

Perhaps it was Czolgosz's seemingly unpronounceable Polish last name, "Its Pronounced Shollgosh" declared one prominent headline in the Chicago Tribune, or the fact that the American media had long portrayed anarchism as an inherently foreign, unAmerican ideology, but, in either case, a surprisingly large percentage of these antianarchist editorials missed or intentionally ignored an essential fact about the assassination of McKinley: Czolgosz was an American. ${ }^{10}$ The assassin's parents may have been from Poland, but Leon was from Detroit. Czolgosz turned to radicalism following the devastating Panic of 1893, when he had lost his job as an iron worker. He struggled for the next several years to achieve any real financial security. ${ }^{11}$ It was economic instability during America's Gilded Age that drove Czolgosz to radicalism and ultimately anarchism, not an inherent foreign inability to understand the American way of life, as was suggested in countless newspaper editorials. His anger was American, his disenchantment was American, and even his anarchism was American.

\footnotetext{
${ }^{9}$ Sunday Oregonian, September 8, 1901, 4.

10 "It's Pronounced Shollgosh," Chicago Sunday Tribune, September 8, 1901.

${ }^{11}$ Miller, The President and the Assassin, 38-41.
} 
While it seemed natural to decry Czolgosz's crime as the actions of a murderous "foreign devil," the assassination was an extreme expression of American discontent at the way in which the country was rapidly undergoing massive structural changes. As the nation became increasingly urban, industrial, and better incorporated into the global capitalist economy, many Americans, including Czolgosz, felt that they were being left behind. The American anarchist movement, which Czolgosz credited as his inspiration, was a product of these same societal transformations. While the movement encompassed people from both immigrant and American-born backgrounds, the anarchism expressed on the pages of its major newspapers and in the speeches of its most well-known figures, was steeped in the culture and history of the United States. ${ }^{12}$ American anarchists frequently cited increased economic disparity between the nation's wealthiest and poorest citizens and growing political corruption as a betrayal of core American values and argued that anarchist communism was the ideal way to authentically reassert these values. This new Americentric focus in the American anarchist communist movement was initially expressed in Portland, Oregon, in 1895 when a small group of ostracized local radicals published the first issue of the Firebrand.

While there had been English language anarchist publications in the United States before the Firebrand, the Portland upstart was the first to effectively introduce anarchist communism to an American audience. By merging the ideas of European anarchist philosophers like the Russian Peter Kropotkin and the Italian Errico Malatesta with

\footnotetext{
${ }^{12}$ For a detailed account of the way in which the English language press acted as a unifying platform for the American anarchist movement in the years following the collapse of the Firebrand see, Brigitte Anne Koenig, "American Anarchism: The Politics of Gender, Culture, and Community from Haymarket to the First World War" (PhD diss., University of California, Berkeley, 2000), xxii-xxiii.
} 
American culture and history, the Firebrand quickly grew from a backwoods publication into one of the most important English language anarchist publications in the world. Emma Goldman, America's most well-known anarchist, recognized the profound influence the Firebrand had on the development of anarchism in the United States. In a 1901 speech, Goldman argued that American anarchism did not begin in New York City or Chicago, where there had been highly active immigrant Anarchist communities since the 1860s, or even in America's heartland where American-born Anarchist Individualists had been preaching a Jeffersonian inspired version of anarchism since before the Civil War. Instead, Goldman argued that the movement truly began in Portland, Oregon in 1895, where a small group of relatively unknown political radicals founded the Firebrand: "the American movement is yet in its infancy, not older than five or six years ... Only since the first issue of the Firebrand, in Oregon, seized by authorities, and now published under the name of Free Society, in San Francisco, have we begun to make headway among the American people."13 According to Goldman, there was something new and quintessentially American about the anarchism being espoused by the Firebrand.

At the time of the Firebrand's publication, their existed two distinct strains of anarchism in the United States: individualist anarchism and collectivist anarchism. While this thesis will focus almost exclusively on collectivist anarchism, of which anarchist communism is a variety, it is important to briefly discuss the history of both movements in order to fully address certain modern historiographical deficiencies. Anarchist

${ }^{13}$ Emma Goldman, “Transcript of 'The Propaganda and the Congress,'” Free Society, April 8, 1900. 
individualism is an older form of anarchism that can be traced back to the work of the American political philosopher and social reformer Josiah Warren during the 1830s. Warren's early work actually predates the development of the modern anarchist movement in Europe, which most historians trace back to the work of French political philosopher Pierre-Joseph Proudhon during the 1840s. Though the Americans would later become aware of and exchange ideas with their European anarchist individualist counterparts, the movement was distinctly American. It was a product of the American individualist tradition and was more inspired by the libertarian principles of Thomas Jefferson and Thomas Paine than by any contemporary European anarchist intellectuals. ${ }^{14}$ The majority of American anarchist individualists were American-born citizens, many of whom had previously been involved in other social justice movements. The anarchist individualists had a particularly strong connection to abolitionism and women's rights activism. ${ }^{15}$ The individualists argued for a society based on absolute personal freedom and were deeply critical of any political or economic organization that could conceivably infringe upon the rights of the individual. By the end of the nineteenth century anarchist individualism in the United States was in decline, completely overshadowed by their collectivist rivals.

Anarchist collectivism first appeared in Europe during the 1860s. This new form of anarchism was championed by Russian political philosopher and revolutionary

\footnotetext{
${ }^{14}$ William O. Reichert, Partisans of Freedom: A Study in American Anarchism (Bowling Green: Bowling Green University Popular Press, 1976), 64-78; Crispin Sartwell, "Introduction," The Practical Anarchist: Writings of Josiah Warren (New York: Fordham University Press, 2011), 1-51.

${ }^{15}$ The anarchist individualist movement's connection to other American social justice movements is discussed in-depth in, Martin Henry Blatt, Free Love and Anarchism: The Biography of Ezra Heywood (Urbana: University of Illinois Press, 1989).
} 
Mikhail Bakunin. The movement would spread to the United States during the 1870s and for the next two decades would remain a primarily immigrant, working class movement based in the insular ethnic communities of the nation's largest cities. The collectivists differed from their individualist predecessors in several ways. Firstly, this new breed of anarchists argued for the complete abolition of private property and for the voluntary collectivization of the means of production. Secondly, the collectivists argued that this non-hierarchical collectivist society should be established through immediate revolutionary action. These ideas ran in stark contrast to the individualists who vehemently opposed collective organization and who argued that even if collectivization was based on the principles of voluntary association it was ultimately an authoritarian practice as one would be forced to subsume themselves to the collective will in order to participate in such a practice. Individualists also tended to argue for a peaceful evolution towards anarchism rather than revolutionary insurrection. ${ }^{16}$

By the 1880s anarchist collectivism was a growing movement in the United States and was especially popular amongst immigrant workers living in the nation's biggest cities. For a time, the movement even seemed to be challenging the ascendency of Marxism. ${ }^{17}$ In Chicago, the collectivist anarchist movement was particularly strong.

\footnotetext{
${ }^{16}$ Paul Avrich, Anarchist Portraits (Princeton: Princeton University Press, 1988), 7-13; Albert Weisbord, The Conquest of Power: Liberalism, Anarchism, Syndicalism, Socialism, Fascism, and Communism, Volume 1 (New York: Covici-Friede, 1937), 245.

${ }^{17}$ The anarchism of Bakunin was in part shaped through his opposition to Karl Marx in the First International. While Marx placed his faith in the industrial proletariat, a natural historical process towards revolution and the need for a phase of dictatorship before the implementation of pure communism, Bakunin put his faith in the peasantry and argued for immediate spontaneous revolution with no intermediate stages. This split between anarchism and Marxism would be mirrored in radical organizations worldwide. Richard Sonn, Anarchism (New York: Twayne Publishers, 1992), 32-33; James Joll, The Anarchists (Cambridge: Harvard University Press, 1980), 67-96.
} 
Bakuninist anarchists and sympathetic revolutionary socialists took leading roles in the city's labor movement through their participation in the International Working People's Association (IWPA), a radical, anarchist leaning labor organization. ${ }^{18}$ The IWPA developed a large and dedicated following amongst Chicago's industrial workers and was particularly popular with German laborers. The collectivist movement's growth came to an abrupt halt following the Haymarket riot of 1886 as the IWPA and its anarchist leadership were targeted in response to the violent incident. The riot had begun as a peaceful, IWPA organized demonstration in support of the national eight-hour work day but exploded into violence when an unknown assailant lobbed a bomb into a group of policemen. The policemen, who had already been pushing into the demonstration in an attempt to bring the event to a premature end, then turned their guns on the demonstrators. In the end, the Haymarket riot resulted in the death of seven police officers and four workers. While the identification of the actual bomber was never determined, local government and national press blamed the local anarchist movement for the incident, and eight anarchists, several of whom had been leaders in the IWPA, were convicted of conspiracy. ${ }^{19}$ The entire affair was covered harshly by the American press, and the death sentence that was given to seven of the Chicago anarchists was, at least in part, the result of the American press's negative portrayal of anarchism. The

\footnotetext{
${ }^{18}$ The party was largely made up of former members of the Marxist Socialist Labor Party (SLP) who questioned the SLP's focus on political tactics and instead argued for direct action in the form of strikes boycott,s and even labor violence. See, Carlos Schwantes, Radical Heritage: Labor Socialism and Reform in Washington and British Columbia, 1885-1917 (Seattle: University of Washington Press, 1979); Bruce C. Nelson; Beyond the Martyrs: A Social History of Chicago's Anarchists, 1870-1900 (New Brunswick: Rutgers University Press, 1988), 66-77.

${ }^{19}$ For a detailed account of the Haymarket Affair see, Paul Avrich, The Haymarket Tragedy (Princeton: Princeton University Press, 1984); Timothy Messer-Kruse, The Trial of the Haymarket Anarchists: Terrorism and Justice in the Gilded Age (New York: Palgrave MacMillan, 2011).
} 
caricature of the violent, foreign anarchist would become a hallmark of the sensationalized news media of the late nineteenth and early twentieth centuries. Ongoing anarchist violence during the 1880s, including the assassination of several European heads of State, would solidify this stereotype, even as the clear majority of anarchists did not support or take part in violent activities.

The Haymarket riot resulted in the rapid decline of the IWPA and halted the growth of the larger American collectivist anarchist movement. ${ }^{20}$ Just a few years later, a new formulation of collectivist anarchism would make its way across the Atlantic, drawing a new generation of Americans to the anti-statist ideals of anarchism. During the late 1880s European anarchist intellectuals began to build upon the loosely defined collectivist principles of Bakunin. The most prominent of these new anarchist philosophers was Peter Kropotkin, a Russian political philosopher, who just like Bakunin, had rejected his own nobility to become a prominent radical reformer. Kropotkin's anarchist communist philosophy built upon the collectivist ideals of Bakunin and posited that while the means of production should be collectivized, goods should be redistributed based on peoples' needs rather than on how much they labored. Though sharing basic principles with Marxist communism, the ideology stood in contrast to Marxism as the communism it promoted was based on the principles of non-coercion and voluntary association. The anarchist communists argued that in a stateless society people would see the benefit of communism and naturally form cooperative workplaces and communities. ${ }^{21}$

\footnotetext{
${ }^{20}$ Kenyon Zimmer, Immigrants Against the State: Yiddish and Italian Anarchism in America (Urbana: University of Illinois Press, 2015), 3-4.

${ }^{21}$ Sonn, Anarchism, 33-41.
} 
Anarchist communism proved to be quite popular in Europe and amongst American immigrant anarchists but struggled to find followers in the United States outside of the nation's insular immigrant communities. It would be the Firebrand publishers who, through their organic embrace of a culturally American perspective, would finally be able to successfully promote anarchist communism to a culturally American audience and address the concerns of readers who lived outside of the movement's urban strongholds. Unfortunately, the work of the Firebranders and the culturally American anarchist movement has largely been overlooked by modern historians.

While historians have long acknowledged the American origins of the nation's anarchist individualist movement, few have recognized the way in which the American anarchist communist movement was also shaped by the history and culture of the United States. Historians have tended to focus on the movement's initial European origins and its popularity amongst urban immigrants and ignored the way in which the movement underwent an organic process of Americanization during the 1890s. The origins of this over-simplistic understanding of the development of anarchist communism in the United States can be traced to the work of Eunice Schuster, an early scholar of the American anarchist movement. Schuster's Native American Anarchism (1932) was a groundbreaking historical account of American anarchist individualism in which she traced the movement's ideological roots back to early colonial religious dissenters. While Schuster's characterization of the individualist movement was bold and innovative, her analysis of the American anarchist communists proved to be lackluster as she argued that 
anarchist communism was an entirely foreign importation, brought to the United States

by European immigrants and exiles during the 1880s and 1890s:

Properly speaking, this type of anarchism [anarchist communism] is not 'native anarchism.' The distinction between the native American anarchism and the type introduced by the foreigner is important, first, as a convenient limitation to the present study, and second, as an explanation of why Anarchist-Communism was rejected and forcibly ejected by the authorities and by the general public. ${ }^{22}$

Schuster highlighted the American qualities of the individualist movement as a means to elevate the ideology while using the foreign elements of the anarchist communist movement as a means to dismiss the movement's importance. While Schuster's work was largely criticized by later generations of historians, the dichotomy that she established between the native anarchist individualism and the foreign anarchist communism remains influential. $^{23}$

For much of the twentieth century, the American anarchist movement in the United States was largely ignored by historians, who had come to see the movement as a relatively unimportant footnote in American history. Works like Schuster's Native American Anarchism were rare as few studies of American anarchism were conducted during the first two thirds of the twentieth century. Conservative, liberal, and Marxist historians all had reasons to dismiss the importance of the classical anarchist movement

\footnotetext{
${ }^{22}$ Eunice Minette Schuster, Native American Anarchism: A Study of Left-Wing American Individualism in Smith College Studies in History Vol. XVIII, Nos. 1-4, October - July 1932, 12.

${ }^{23}$ Examples of studies that perpetuate Schuster's dual origin theory of American anarchism include, James J. Martin, Men Against the State: The Expositors of Individualist Anarchism in America, 1827-1908 (Colorado Springs: Ralph Myles Publishers, 1970); David DeLeon, The American as Anarchist: Reflections in Indigenous Radicalism (Baltimore: John Hopkins University Press, 1978); Jessica Moran, "The Firebrand and the Forging of a New Anarchism: Anarchist Communism and Free Love," The Anarchist Library, https://theanarchistlibrary.org/library/jessica-moran-the-firebrand-and-the-forging-of-a-new-anarchismanarchist-communism-and-free-lov.
} 
and it was not until the rise of social history and New Left politics during the 1960s that scholars began to truly evaluate anarchism in the United States. Due to the negligence of the previous generation, the historians of the 1960s and 1970s had to act as both preservationists and historians, seeking out and saving what sources they could. Paul Avrich, whose work in the field of both Russian and American anarchist history remains essential to this day, was first among these historians. ${ }^{24}$ This generation of historians focused heavily on publishing biographies and general studies of the international anarchist movement and therefore, in-depth historical analysis of the American anarchist movement was rare. William Reichhert's Partisans of Freedom: A Study in American Anarchism (1976), is an exception to this trend. The book provided a detailed overview of American anarchism, with a focus on intellectual history. Reichert was one of the first historians to challenge Schuster's characterization of the American anarchist communism movement by acknowledging the role that American culture and history played in the development of the American anarchist communism. He even included a short chapter about the Firebrand, in which he noted that the publishers came from non-immigrant backgrounds and approached anarchism from an American perspective. Reichert described the Portland anarchists as "[g]ood Americans all, they possessed solid Yankee names and were dedicated to the reform of American society before the defects in its social structure became so deep and bitter that they would destroy the land of hope and

\footnotetext{
${ }^{24}$ Avrich embedded himself within New York City's Yiddish anarchist community during its final years of existence during the 1970s. The community had organized itself around long running the newspaper Freie Arbeiter Stimme since 1890. He also conducted interview with surviving members of the classical anarchist movement. This includes interviews with the grandchildren of Firebrand publisher Abraham Isaak, which were invaluable to this research project.
} 
freedom. ${ }^{" 25}$ While Reichert's work highlighted the Firebrand's novel American perspective, it did not address the way in which this perspective was informed by the Firebrand publishers' western identities and experiences living in Gilded Age Portland. ${ }^{26}$ Labor historian Carlos Schwantes' 1981 article, "Free Love and Free Speech on the Pacific Northwest Frontier: Proper Victorians Vs. 'Filthy Firebrands,"” is an excellent, albeit brief, discussion of the Firebrand that focuses heavily on the way in which local factors shaped the newspaper's content. Schwantes framed the Firebrand in the context of a struggle between lewd anarchists and a morally prudish, "Victorian" Portland society, focusing heavily on the obscenity trial that would eventually bring an end to the paper's publication. ${ }^{27}$ In recent years, historians have moved away from this characterization of Portland by acknowledging that while Portland may have been less radical and tumultuous than Seattle and Tacoma to the north, characterizing Portland as a "conservative, family centered, money making church-going society," is an oversimplification born from the city's own efforts to promote itself as such. ${ }^{28}$ Therefore, this thesis will build upon Schwantes' work by illustrating the way in which the anarchism of the Firebrand was influenced by the city's more radical, less refined

\footnotetext{
${ }^{25}$ Reichert, Partisans of Freedom, 261.

${ }^{26}$ See also, Brigitte Anne Koenig, "American Anarchism: The Politics of Gender, Culture, and Community from Haymarket to the First World War" (PhD diss., University of California, Berkely, 2000). Koenig provides a detailed account of the Americanization of the anarchist communist movement at the turn of the century and discusses the significant role that the Firebrand and its successors played in this movement, but, like Reichert, does not discuss the way in which this perspective was influenced by the Firebrand publisher's unique perspective as Portlanders or as westerners.

${ }^{27}$ Carlos A Schwantes, "Free Love and Free Speech on the Pacific Northwest Frontier: Proper Victorians vs. Portland's 'Filthy Firebrand,'” Oregon Historical Quarterly 82, no. 3 (1981): 271-293.

${ }^{28}$ Schwantes, "Free Love and Free Speech on the Pacific Northwest Frontier," 271. For a description of the ways in which Portland defied this Victorian stereotype, see Carl Abbott, Portland In Three Centuries: The Place and the People (Corvallis: Oregon State University Press, 2011), 59-64.
} 
elements, particularly its growing population of agitated, unskilled laborers who migrated to the city in increased numbers following the Panic of 1893 . The only other piece of historical writing dedicated entirely to the subject of the Firebrand is Jessica Moran's "The Firebrand and the Forging of a New Anarchism: Anarchist Communism and Free Love." In the article, Moran acknowledges the Firebrand's foundational role in the development of the American, English Language anarchist communist movement but largely ignores the way in which the newspaper's unique Americanized perspective was shaped by local and regional influences. Moran instead argues that the Firebrand borrowed many of these elements wholesale from the Anarchist individualist movement. Moran therefore perpetuates Schuster's dual origin theory of American anarchism and dismisses the truly organic Americanization of the anarchist movement that first occurred during the Firebrand's run. ${ }^{29}$

The theoretical framework of this thesis is indebted to historian Kenyon Zimmer's work on immigrant anarchism in the United States. In Immigrants Against the State: Yiddish and Italian Anarchism in America (2015), Zimmer argues that immigrant anarchism in the United States was not simply a wholesale importation of European ideology, in which already converted anarchists simply immigrated to the United States. Instead, Zimmer argues that most American immigrant anarchists did not arrive in the United States as anarchists, or even as radicals, but were driven to anarchism by the circumstances in which they found themselves in the new world. The disillusionment felt

\footnotetext{
${ }^{29}$ Jessica Moran, "The Firebrand and the Forging of a New Anarchism: Anarchist Communism and Free Love," The Anarchist Library, Online, 2004. https://theanarchistlibrary.org/library/jessica-moran-thefirebrand-and-the-forging-of-a-new-anarchism-anarchist-communism-and-free-lov.
} 
by many immigrants upon arrival in the supposed promised land of America, where they found themselves packed into tenements and working in dangerous exploitative sweatshops, was the driving force behind immigrant anarchism in America. ${ }^{30}$ This thesis takes this argument and applies it to the culturally American anarchism of the Firebranders which I argue is the product of a particularly western form of disillusionment, in which recent arrivals to the American west were dismayed at the lack of economic opportunity and high levels of political corruption in what was supposed to be the promised land of the American frontier.

One of the biggest deficiencies within anarchist historiography has been the inability of historians to properly illustrate the significance of their subject matter. This is especially true of historical writing concerning anarchism in the United States, where the classical anarchist movement of the late nineteenth to early twentieth century remains a footnote in the larger story of radical activism in American history. This historiographical deficiency is difficult to comprehend considering the sheer number of anarchists who have played notable roles in late nineteenth and early twentieth century American history: the Haymarket Martyrs, Alexander Berkman, Leon Czolgosz, Sacco and Vanzenetti and of course Emma Goldman who is, arguably, the most well-known radical in American history. These men and women appear, suddenly, with little explanation, onto the pages of American history textbooks, usually as spontaneous, disconnected arbiters of violence and terror, only to immediately disappear with little mention of the larger anarchist

${ }^{30}$ Zimmer, Immigrants Against the State. 
movement from which they came. Unfortunately, outside of those who study the subject, anarchism continues to be left out of the larger narrative of American history.

More than just a series of disconnected individuals and acts of terror, anarchism was both a political and a cultural movement that, in its classical period, lasted from the 1870 s to the early 1920 s. The publication of the Firebrand marked a transitional moment in the history of American anarchism, in which a new culturally American formation of anarchism became the preeminent perspective within the movement. Though the movement never attained an overwhelming number of followers in the United States, anarchism proved to be incredibly influential, as many of its ideas were adopted by other, more popular, radical movements. The American syndicalist movement, the free speech movement, and the American anti-war movement during World War I all had strong ties to the culturally American anarchist movement. Though not even lasting three years, the Firebrand would transform the landscape of radicalism in the United States. 


\section{Chapter I: Radicalism in Portland and the Origins of the Firebrand}

"Comrades Mary Squire, A. Isaak, E. Slabs, John Pawson and myself visited the meetings in the city where a free discussion was had and accasionally[sic] took part in the discussions. We tried to get our ideas in the local 'reform' press. We finally found all the columns of the press closed against us except on the condition we 'trim' our conditions. We talked the matter over and concluded to start a paper."

To truly understand the unique development of the Firebrand and the profound impact the newspaper would have on American radicalism during the Progressive Era, it is necessary to understand how the Firebranders' perspectives were shaped by their experiences in Portland during the early 1890s. The core publishers of the Firebrand were all active within Portland's local radical community during the 1890s, and their rejection by the various organizations and political parties that made up that community was the central factor in their decision to start their own newspaper. There were few anarchists in Portland and these radicals experienced severe censorship and ostracization. They therefore wanted their newspaper to be a place of open discussion rather than a static piece of propaganda, a place where similarly silenced radicals felt free to send in their own opinions and ideas and contribute to an open conversation. The Firebrand publishers were a unique collection of Portland radicals whose background and class identity shaped the way in which they participated in their local community. The Firebranders were almost all members of a growing class of unskilled Portland laborers who were struggling to survive on the margins of Portland society, especially following the devastating Panic of 1893. Miners, loggers, farm laborers, itinerant workers, struggling farmers, and unskilled industrial workers were the Firebrand's cohort and its

\footnotetext{
${ }^{31}$ Henry Addis, "The History of the Firebrand," March 8, 1896, 3; Moran, "The Firebrand and the Forging of a New Anarchism."
} 
audience. The Firebranders found the established local radical community to be elitist, condescending, and unwilling to represent this growing class of marginalized workers. Whether it be the pomposity of the local socialist discussion group "The Academy of Socialism," the exclusivity of the city's Central Labor Union, or the political capitulations of a declining Populist Party, the Firebranders felt alienated from Portland's established local radical community. The Firebranders' disillusionment with traditional radical and reformist tactics led them to take increasingly extreme positions, resulting in their ostracization from the city's various far left organizations and their eventual embrace of anarchist communism.

The purpose of this chapter is to provide a brief biographical sketch of four of the Firebrand's most prominent Portland publishers and contributors, Mary Squires, Henry Addis, Abraham Isaak, and J.H. Morris, and analyze the way in which these radicals' experiences in Portland during the 1890s led them to not only embrace anarchist communism but to develop a new, organically American, expression of the ideology that would connect with and influence American radicals for decades to come.

\section{Mary Squires}

"Mrs. Squires, woman like, had made up her mind that the baby which soon would make its entrance into this cold and wicked world of ours should come into it with a fighting name; a name which indicates aggressiveness and would strike terror to the hearts of evil doers, and therefore decided on 'Firebrand. "',32

Before the publication of the Firebrand, Mary Squires was known in Portland as a fiery street speaker and an uncompromising radical. It is therefore quite appropriate that it

32 Ezekiel Slabs, “God Government and Greed," Firebrand, January 27, 1985, 4. 
was Squires, very much a firebrand in her own right, who gave the newspaper its name. ${ }^{33}$ While Squires would disappear from the pages of the Firebrand only a year into its publication, the many articles that she contributed to the newspaper during this short period articulated a powerful critique of both Portland high society and the city's radical community, attacking the city's labor movement with particular ferocity. Squires laid bare the inherent contradictions of Portland radicalism and skillfully presented anarchist communism as a valid alternative solution to the city's numerous problems, illustrating a path forward for a movement that had long struggled to explicate its ideas to the culturally American worker. Squires' political radicalism, particularly her unflinching belief in the revolutionary potential of the unskilled American laborer, was a direct product of her experiences living in Portland during the early 1890s, when, following the devastation of the Panic of 1893, the city seemed at times on the verge of violent class conflict.

Unfortunately, there is little information regarding Squires' life before her arrival in Portland in the early 1890s. It can be inferred that she was married, as she was frequently referred to as "Mrs. Squires" in the Oregonian, though no information was ever given regarding a husband or family. The Oregonian also provided a brief description of Squires in its coverage of her time in Portland, describing her as "middleaged" and "willowy." 34 Squires likely moved to Portland from San Francisco where she had helped to establish a labor exchange and where she would frequently visit while

\footnotetext{
${ }^{33}$ Other proposed titles included The Red Flag, Free Society, Dive's Lament and The Bitter Truth. Slabs, "God Government and Greed," 4.

34 “Mrs. Squires Arrested: The Female Agitator Figures in a New Role," Oregonian, August 4, $1895,20$.
} 
working on the Firebrand. ${ }^{35}$ In Portland, Squires worked as a corset maker and was therefore an entrenched member of Portland's working class. While in Portland, Squires participated in various local populist, socialist, and labor organizations but was always castigated as an outlier in the city's relatively conventional radical movement. Squires therefore made her biggest impact working outside of these organizations.

Following the Panic of 1893, Squires gained a reputation as an influential street speaker, finding an audience amongst the city's growing population of unemployed and homeless laborers. Squires often addressed crowds in local plazas and parks, where this growing underclass tended to congregate, much to the chagrin of the city's leadership. Squires' radical appeals to the city's most destitute citizens frightened the local establishment and drew the ire of the Republican, business minded Oregonian who depicted her as an incessant troublemaker, a "ranting orator" whose purpose was to "preach all sorts of inflammatory and seditious measures."36 The Oregonian's sensationalist coverage of a legal dispute between Squires and a former roommate may have even been a factor in her decision to leave Portland in $1896 .{ }^{37}$ Squires then travelled to California, where she initially continued to contribute articles to the Firebrand but eventually disappeared from the newspaper and from the larger American anarchist movement. Squires acted as the Firebrand's conscience, pushing the newspaper to take a

\footnotetext{
35 "Vision of the Red Flag, Fears Inspired by the Existence Here of the Commonwealth," San Francisco Call, July 12, 1895, 4; "They May Look Well on Paper," The Dalles Chronicle, May 16, 1895, 1.

36 "A Demand Made by the People Who Loaf on the Plaza," Morning Oregonian, June 15, 1894, 5.

${ }^{37}$ Coverage of Squires legal dispute can be found in "“Mrs. Squires Arrested," Morning Oregonian, August 4, 1895, 20. For Squires conviction and statement about her intentions to leave Portland see, "City News in Brief", Morning Oregonian, August 6, 1895, 5.
} 
firm stance on two central issues: the absolute rejection of political tactics and a deep belief in the revolutionary potential of the American people.

Squires first came to the public's attention as an agitator for the Portland contingent of Coxey's Army. It was from this position that Squires gained a reputation as a particularly fierce orator and a radical outlier to the more conservative Portland labor movement. ${ }^{38}$ Coxey's Army was a national protest march of unemployed workers organized by Ohio businessman Jacob Coxey in 1894. The goal of the march was to bring an army of unemployed American workers from across the nation to Capitol Hill in Washington D.C. to demand the implementation of a jobs program to alleviate the devastating impacts of the Panic of 1893. The original march left Massillon, Ohio on March 25, 1894 and arrived in Washington on May 1, 1894 with a contingent of fivehundred men. The march was ultimately a failure as Coxey and his supporters were immediately detained once they reached the Capitol Building, arrested for the crime of trespassing on the lawn of the Capitol. ${ }^{39}$ Other industrial armies were formed in the Western United States, most of which sought to join up with Coxey in the Nation's capital, the largest of these armies came from California, but very few of the western marchers made it past the Rocky Mountains. ${ }^{40}$

\footnotetext{
${ }^{38}$ Despite Squires involvement in several different radical organizations, whenever mentioned in the Oregonian Squires is always identified based on her association to the Coxey Movement. Examples of this can be found in "A Charter Favored: Meeting Called to Denounce Resolves to Indorse" Morning Oregonian, February 10, 1895, 8; “"Mrs. Squires Arrested” 20.

${ }^{39}$ Carlos A. Shwantes, "Western Women in Coxey's Army," Arizona and the West 26, No. 1 (Spring, 1984): 19-20.

${ }^{40}$ Schwantes, Radical Heritage, 57-58.
} 
The Coxeyite industrial armies that were formed in the Pacific Northwest were notably more radical than their eastern and Californian counterparts. Marchers in several major Northwest Cities, including Seattle, Tacoma, Butte, Portland and Spokane, formed their own industrial armies that notably came into frequent conflict with law enforcement and the National Guard on their eastward marches. ${ }^{41}$ The story of the Portland contingent of the Coxey army fits this trend of regional violence, and the events surrounding the Portland contingent's attempted eastward march left an indelible impression on Squires. The events convinced her of the revolutionary potential of the city's most despondent citizens and the effectiveness of direct action, setting her at odds with the city's traditional labor activists.

The formation of the Portland branch of Coxey's Army was a direct response to the catastrophic consequences of the Panic of 1893 and the devastating economic depression it created. The Panic of 1893 was just one of many economic panics that occurred during the nineteenth century, a byproduct of an increasingly interconnected global economy in which events in far-away countries could trigger economic devastation at the local level. The economic panic would transform into the second worst economic depression in American history, lasting from 1893 to 1897. The Panic resulted in the collapse of hundreds of banks and businesses across the country and at its height, the unemployment of four million people..$^{42}$ Massive unemployment resulted in an increased numbers of itinerant workers, as thousands of laborers traveled from city to city

\footnotetext{
${ }^{41}$ Schwantes, "Western Women in Coxey's Army," 6.

${ }^{42}$ Herman C. Voletz, "Coxey's Army in Oregon, 1894," Oregon Historical Quarterly 65, No. 3 (September 1964): 263.
} 
looking for employment. ${ }^{43}$ Many headed west, expecting to find more opportunity in what had once been the American frontier, only to find conditions were much the same. While Portland did not face the same level of devastation as did its rivals to the North in Seattle and Tacoma, the city was hard hit by the Panic. ${ }^{44}$ Major regional industries suffered considerably, and railroad construction, a major employer in the region, halted. Portland rapidly became a haven for unemployed and homeless workers who had previously been working on railroad projects or in similarly impacted extractive industries like logging, mining, and fishing, in the surrounding countryside. Conditions in Portland became so dire that during the winter of 1893 Mayor William S. Mason personally donated four hundred sacks of flour to the city's unemployed and impoverished citizens, fearing that they would otherwise starve. ${ }^{45}$

Conditions in Portland continued to worsen during the Spring of 1894. Thus, when fifty members of the San Francisco contingent of the Coxey crusade arrived in Portland seeking recruits they were easily able to find hundreds of volunteers. The Portland contingent grew quickly, much to the dismay of the city's political and business leaders who hesitantly allowed the Coxeyites to make camp in Sullivan's Gulch on the banks of the Willamette, initially providing them with food to prevent panhandling and vagrancy. Eventually the Coxeyites marched to the city of Troutdale, just east of Portland on the Columbia River, where they attempted to secure a train for their eastward journey.

\footnotetext{
${ }^{43}$ Voletz, "Coxey's Army in Oregon, 1894," 263.

${ }^{44}$ For a description of the results of the Panic of 1893 in Tacoma, see Murray Morgan, Puget's Sound: A Narrative of Early Tacoma and the Southern Sound (Seattle: University of Washington Press, 1979), 274277.

${ }^{45}$ E. Kimbark MacColl, Merchants, Money, and Power: The Portland Establishment 1843-1913 (Portland: The Georgian Press, 1988), 309.
} 
Despite sympathetic governor Sylvester Pennoyer advocating on their behalf, authorities denied the Coxeyites rail passage. The marchers then took matters into their own hands and commandeered a train, which they rode as far as Arlington, 120 miles east of Portland on the Columbia River, before the train was halted by the national guard and the marchers, 446 in total, were arrested. ${ }^{46}$ The arrest of the Portland marchers was not the end of the Coxey agitation in Portland. The arrested men quickly became local heroes and thousands flooded the streets to demonstrate against their arrest. The federal judge in charge of overseeing the trial of the Portland Coxeyites seemed uninterested in punishing the marchers and after securing apologies from the army's leaders, freed them all. The acquittal resulted in an impromptu celebration on the streets of Portland, in which an estimated three thousand men and one hundred women came out to celebrate a victory for the city's desperate working class. The revelers even held an impromptu demonstration outside of the Oregonian building in which the Coxeyites and their supporters vociferously condemned the newspaper for its attacks against the marchers. ${ }^{47}$ Direct action had resulted in a small defeat for Portland's entrenched elite establishment who came to fear Portland's growing unemployed and homeless population and worked diligently to prevent another gathering of such a group. Coxey's Army was an important event for the publishers of the Firebrand as it helped to shape their faith in the revolutionary potential of the city's most destitute citizens.

${ }^{46}$ MacColl, Merchants, Money, and Power, 309-310.

${ }^{47}$ Voletz, "Coxey's Army in Oregon, 1894," 289-290. 
While most women participated in the Coxey movement as members of women's auxiliary groups, Squires seems to have played a more direct role in the agitation. ${ }^{48}$ The Oregonian later described Squires as "a conspicuous figure in the Coxey army movements" and described her actions thusly: "[d]uring the Coxey agitation, Mrs. Squires, carrying a long pole to which was attached a piece of white muslin, tried hard to rally those of her sex under what she called her banner of peace. She would deliver harangues on the plaza to restless crowds of idle men." ${ }^{.49}$ Squires seems to have participated in the many public gatherings held in support of the Coxey movement, developing a reputation as a fierce female supporter of the cause. Despite having been an active member in dozens of other local radical causes, the local press would continue to refer to her thereafter as "Mary Squires, of the Coxey army."

Having experienced firsthand the power of direct action during the Coxey agitation, Squires had little patience for the slow pace and conservative approach taken by local radical organizations and political parties. In the lead up to the 1894 midterm congressional elections, Squires frequently spoke on behalf of the Populist Party. Despite her tacit support for the united fusionist Democrat-Populist ticket, known locally as the "demo-populists," Squires remained one of the city's most controversial speakers as she frequently mocked the party she was supporting by attacking the inescapably corrupt

\footnotetext{
${ }^{48}$ For the most part, women did not march in the industrial armies. Instead, most women formed home guard and auxiliary units that supported the marchers by sending them the "amenities of life," such as clothes and food, and by also taking care of the marchers' families while they were away. For more information on the role of Women during the Coxey movement, see Schwantes, "Western Women in Coxey's Army in 1894," 5-20.

49 "Mrs. Squires Arrested: The Female Agitator Figures in a New Role," 20.

50 "A Charter Favored," Sunday Oregonian, February 10, 1895, 8.
} 
nature of Portland politics and even questioned the effectiveness of democratic elections as means for creating real change for the working class. ${ }^{51}$ In an article titled "Her Unlordly Language," the Oregonian, with its staunchly pro-big business and proRepublican perspective, attacked Squires for her radicalism, stating:

A demo-populist meeting last evening on Burnside Street, between second and third, was addressed by Mrs. Squires, whose language was more forcible than polite. She told her amused audience that it is their duty to accept all the money beer they may be offered for their votes, and then to 'vote as they $d-d$ please.' This petticoated orator is the idol of the anarchistic element. ${ }^{52}$

Even as she agitated for the Populist ticket, Squires seemed deeply pessimistic regarding the possibility of creating change through traditional political channels. Following the 1894 elections, in which populists failed to make any significant gains, Squires distanced herself from electoral politics. Instead, Squires focused on promoting direct action tactics through her work as a public speaker. The Panic of 1893 had devastated the city's working class and resulted in the growth of the city's underemployed, unemployed, and homeless populations. With nowhere to go, Portland's impoverished were beginning to gather in the city's parks and public spaces. The resulting fear regarding the city's growing unemployed and homeless population can be seen on the pages of the Oregonian. "The plaza blocks are beginning to be considered a sort of public nuisance," wrote one journalist, "on account of the crowd of loafers and unemployed persons who

\footnotetext{
${ }^{51}$ Despite Squire's increasingly anarchistic beliefs and rhetoric, she does seem to have, at one point authentically supported the Populist cause and was noted as being "conspicuous on the platform," when Oregon Governor Sylvester Pennoyer, a populist sympathizer, addressed a populist rally during the 1894 elections. "Nearing the Close: Campaign Will End Tonight," Morning Oregonian, June 2, 1894, 8.

52 "Work of Rowdies Hurting Mongrel Ticket: Her Unlordly Language," Morning Oregonian, May 28, 1894, 8.
} 
make them a haunt day and night, lying about in the grass and smoking or snoozing under the trees." 53 Downtown Portland's Lownsdale Square, long a center of radical activity and protest, had a particularly notorious reputation and was described in the same article as "a sort of headquarters for the gang, which numbers around 200, and is from time to time occupied by ranting orators, male and female who were populists before the election and are now agitators and jawsmiths." The journalist pointed to Mary Squires as one of the more notorious local jawsmiths, stating that she had been lecturing the crowd on "money, the lack of it and how to get it, and other abstruse subjects." ${ }^{54}$ When Squires was not raising hell in the Plaza, she was doing so in the city's various local socialist, labor and reform meetings, critiquing what she saw as their ineffective strategies.

\section{Portland Labor Activism}

Portland, though not nearly as industrialized as the nation's larger eastern cities, had a sizable working-class population that made up roughly $50 \%$ of those listed in the 1892 Portland directory. Labor organization began early in the city's history when, in 1853, the typographers of Oregon and Washington formed the city's first union. Organization efforts steadily grew during the next two decades and by the 1870 s the city's longshoremen, shipwrights, railroad workers, typographers and printers all had formed permanent unions, and the city experienced some of its earliest strikes at the hands of local deckworkers and longshoremen. During the 1880s economic difficulties and growing anti-Chinese sentiment steered the city's labor movement in a more radical direction. During the 1880s, the Knights of Labor rode the rising tide of Sinophobia to

53 "A demand made by the people who loaf on the Plaza," Morning Oregonian, June 15, 1894, 5. 54 Ibid. 
become one of Oregon's most prominent labor organizations. ${ }^{55}$ During the 1880 s and 1890 s, there existed a duality in Oregon's labor movement in which two different labor ideologies coexisted. The first being the older "producerism" as embodied by the Knights of Labor, which advocated for laborers, regardless of profession, arguing that all laborers should organize together to challenge employers. The other ideology was "Craft Unionism" which organized unions based on trade, such as those associated with the Associated Federation of Labor at the national level and the Federal Trades Assembly of Portland (FTA) and the Central Labor Union at the local level. Craft unionism in Portland was in the process of becoming the more dominant force in the city and the local movement was shifting its focus towards "bread and butter issues" like wages, hours, and workplace safety. ${ }^{56}$ The Firebranders came from a radical producerist tradition, even promoting Knights of Labor meetings in the newspaper. This was in part because the Firebrand publishers were primarily unskilled laborers, and therefore less likely to be able to join a craft union.

Squires and the other Firebranders had been attending local labor meetings in the Portland area for some time and it seems that their unconventional demands for immediate direct action had caused considerable controversy. At one point, the anarchists' agitation at meetings of Portland's Central Labor Council, a city-wide

\footnotetext{
${ }^{55}$ Workers in the Pacific Northwest saw Chinese labor as a threat to job security and Anglo-American identity and organized to expel the region's Chinese population. Sinophobia became so severe in the Pacific Northwest that during the 1880s there were a series of anti-Asian race riots in which Asian populations were forcibly removed from several Pacific Northwest communities. See, Jean Pfaelzer, Driven Out: The Forgotten War Against Chinese Americans (New York: Random House, 2007).

${ }^{56}$ William Haas Boyer, Oregon Politics and the Evolution of the Populist Movement in Portland, 1880-1898 (PhD diss., University of Oregon, 2003), 48-52; Schwantes, Radical Heritage, 25-26.
} 
organization of craft unions, had caused the council to pass a resolution that upheld the ballot as the "only remedy for present social evils." ${ }^{, 57}$ In an opinion piece published in the Firebrand's third issue, Squires argued that the organization passed this resolution to oppose the anarchists, who she claims were directly referred to in the language of the resolution as "half a dozen so-called anarchists, posing as laborers, but whose labor, in fact, consists chiefly of jawbone," and who sought to "abolish law and order in any form, and institute anarchy and disorder, including the abolition of marriage and the sacredness of home." 58 Squires and her fellow anarchists had upset the status quo through their brazen rejection of the state and their unyielding attacks on traditional marriage and had therefore been dismissed as a small band of irrational agitators by the local labor movement.

Although Squires was an influential founder of the Firebrand, she would leave Portland in early 1896 following a legal dispute with a former roommate. According to a sensationalized account in Oregonian, Squires was arrested on August 3, 1895 on charges of "trespass and assault and battery." Squires had entered the home of her former roommate, Elizabeth Somers, to retrieve a possession while she and her husband were out of the house. Somer's fourteen-year-old daughter was home and attempted to bar Squire's from the premise, only to be moved aside by Squires who grabbed her arm so hard that, according to the Oregonian, she left a mark. Squires was convicted and heavily fined. Afterwards, Squires claimed that she would leave Portland for San Francisco. ${ }^{59}$

\footnotetext{
57 "Snatched from the Burning," Firebrand, February 10, 1895, 4.

58 Ibid.

59 "Mrs. Squires Arrested," 20; "City News in Brief," 5.
} 
According to the Firebrand, Squires travelled to California on a propaganda tour and intended to remain a regular contributor to the newspaper. While she did contribute a few articles to the newspaper while living in San Francisco, her contributions eventually ceased without explanation. Despite her abrupt disappearance, Squire's incisive critiques of the local political establishment and labor movement, honed through her time as a street speaker, helped the Firebrand to position itself as a champion of America's most desperate citizens and as a critic of the country's existing radical and reformist movement.

\section{Henry Addis}

Due to its publishers' commitment to non-authoritarian anarchist principles, the Firebrand had no named editor or manager, but over time, Henry Addis became the newspaper's most prominent figure. This was largely due to the sheer number of articles he wrote for the publication, as well as the vital role he played behind the scenes copyediting, setting type, and physically printing the paper. ${ }^{60}$ Addis was born in Iowa in 1864 and lived in Colorado before arriving in Portland in $1890 .{ }^{61}$ As a life-long westerner who could trace his ancestry in the United States back to the seventeenth century and who claimed to be a "descendent of a family that came to this continent with Wm. Penn," Addis clearly did not match most Americans conceptualization of an anarchist. ${ }^{62}$

\footnotetext{
${ }^{60}$ Schwantes refers to Addis as the "First among equals," see, Schwantes, "Free Love and Free Speech on the Pacific Northwest Frontier," 277.

${ }^{61}$ According to census records, Addis was at the time married and had three children. This fact is never mentioned by Addis or any of his cohort in the Firebrand, see Oregon. Multnomah County. 1900 U.S., population schedule. Digital images, Ancestry.com. January 20, 2018. http://ancestry.com.

62 Henry Addis, The Firebrand, March 31, 1895, 3.
} 
While Addis provided little detail about his life before his arrival in Portland, it seems likely that he was already involved in the American radical movement to some degree, because almost immediately after his settlement in Portland he became heavily involved in several local radical and reform organizations. Addis first appears in the historical records in Portland through his involvement in the foundation of Portland's first free library in 1891, a venture that involved some of the state's most recognizable progressive political figures. A year later Addis attended the founding convention of the Oregon People's Party, the state's Populist political party, and would later become a prominent local populist politician, running for local office multiple times during the 1890s. While Addis would later criticize the Populist Party, he acknowledged that the party positively shaped his opinions on a variety of issues, particularly in regards to the subject of rural land use. Addis had also been a member of the Socialist Labor Party (SLP), an America Marxist political party, during the early 1890s. The SLP's use of censorship, its dogmatic tendencies and the dictatorial role played by the party's leader, Daniel DeLeon, pushed Addis away from a more moderate socialist position towards an embrace of anarchism.

While progressive reform, populism and state socialism had the most demonstrable impact on Addis and his writing in the Firebrand, Addis, like all of the Firebranders, was involved in several other interrelated radical and countercultural movements. For example, Addis seems to have been involved in the free thought movement as a member of the Rainier Secular Union, was the Secretary of the Oregon Vegetarian Society, and later in life participated in the local Grange and single-taxers 
movements. ${ }^{63}$ The Firebrand anarchists were part of a larger Progressive Era countercultural movement in the United States, in which ideas frequently moved from one movement to the next.

\section{Progressive Reform}

Just a year after arriving in Portland, Addis helped to found Portland's first free library, the People's Free Reading Room and Library Association in $1891 .{ }^{64}$ The concept of a free library was new and radical in the city of Portland. The city's previously existing libraries were subscription based, catering almost exclusively to wealthy patrons. The opening of the free library was a part of the progressive spirit of the late nineteenthcentury in which new egalitarian approaches to education were popularized and wealthier members of society sought to uplift lower class citizens through the funding of educational institutions. This paternalistic relationship between the city's elite and its most desperate citizens was exemplified by a quote given by one Free Reading Room worker in the Oregonian: "If we can keep young, middle-aged and old men away from the strong temptation of the saloons we are accomplishing a great deal of good. That is the object of the free reading room." According to the library worker, the reading room had been supported by the city's elite: "we have called upon a good many of the business and professional men of Portland for assistance, and, with few exceptions, all have

\footnotetext{
${ }^{63}$ For a reference to Addis's involvement in the Secular Union, see "Free Thinker's Exercises," Hillsboro Independent, June 8, 1894, 2. For a reference to Addis's election as the Secretary of the Oregon Vegetarian Society see "In Other Days: Twenty-Five Years Ago," Oregonian, January 18, 1917, 10. For a reference to Addis's involvement in the Grange see "Favor Separate Schools," Morning Oregonian, February 18, 1907; For a reference to Addis's participation in the Oregon Single Tax Movement, see "Will submit Amendment to Constitution to Voters: Some Drastic Provisions," Daily Capital Journal, May 2, $1912,6$.

${ }^{64}$ Morning Oregonian, "Monument to Mr. Thompson: What he did for Portland's First Free Library" December 21, 1901.
} 
cheerfully contributed toward the work." ${ }^{\circ 5}$ Despite the involvement of radicals like Henry Addis, quotes like these reveal the way in which the library was largely a creation of the Portland establishment who sought to reform the rougher elements of their growing city.

It is curious that a self-described underemployed and unskilled laborer would be so involved in the foundation of such an important institution, mixing company with some of Portland's most prestigious citizens. Addis was later described by the Oregonian as, "a mild-mannered young man living in South Portland. He has no settled occupation, but works at whatever offers when he needs work. He has been a canvasser, a corn doctor and a gardener at various times. ${ }^{" 66}$ Regardless of Addis's background, he was a founding member of the Reading Room, and for an unknown amount of time, its librarian. ${ }^{67}$ In this role, Addis rubbed elbows with Portland's progressive elite, those members of the Portland business and political establishment who had embraced and financially supported the progressive reform movement. Sitting Democratic governor of Oregon and future Portland mayor, Sylvestor Pennoyer, and former Idaho governor and prominent Portland politician D.P. Thompson, were both involved in the foundation of the reading room. Pennoyer was well known as an advocate for the local labor movement and a strong supporter of, and eventual member of, the Populist Party. Thompson, on the other hand, was a fairly conservative politician with certain progressive tendencies who took part in the effort because he believed a free library would be to the benefit of the general

\footnotetext{
65 “People's Free Reading Room,” Morning Oregonian, March 7, 1891, 9.

66 “Few Portland anarchists," Morning Oregonian, September 12, 1901, 12.

${ }^{67}$ Addis is listed as the Reading Room's librarian on Free Reading Room Letterhead that was used by Oregon suffragette Abigail Scott Duniway to list members of the Oregon State Secular Union. Oregon State Secular Union subscribers roster, folder 12, box 3, Abigail Scott Duniway Papers, Mss 432 , Oregon Historical Society, Davies Family Research Library, Portland, Oregon.
} 
public. ${ }^{68}$ It was in this context that Addis would come into contact with the city and state's progressive and populist elite, the very same people he would lampoon and vilify just a few short years later while publishing the Firebrand. While Addis never directly mentions his role in the library's foundation in the pages of the Firebrand, he often used figures like Pennoyer and Thompson as examples of the folly of electoral politics, as such men campaigned on radical and reformist platforms but then once in power, according to Addis, governed the same as their predecessors.

The trajectory of the Free Reading Room during the early 1890s follows Addis' same descent into radicalism. When the Free Reading Room first opened, it was quite reputable and was well regarded by the Portland establishment. The room seemed to fulfill its promised intention of uplifting the city's most despondent citizens and many of the city's business minded Republican leadership supported the library. But they were unaware of the institution's gradual leftward shift towards socialism and anarchism.

Soon after its founding, the Reading Room became a meeting place for several local radical organizations. For example, the Portland chapter of the Secular Society, a freethought organization that championed science and reason over superstition and religion, held regular meetings in the reading room. ${ }^{69}$ For a short while, the Firebrand publishers held an anarchist discussion group in the reading room. Likely under the leadership of Addis and his cohort, the Reading Room eventually became a known center of radical activity, so much so that in 1897 , right around the time of the arrest of the

68 "Monument to Mr. Thompson," 3.

${ }^{69}$ Portland chapter of the Secular Society was led by the famous Oregon suffragette Abigail Duniway Scott. Oregon State Secular Union subscribers roster, folder 12, box 3, Abigail Scott Duniway Papers, Mss 432, Oregon Historical Society, Davies Family Research Library, Portland, Oregon. 
Firebrand publishers, the Morning Oregonian published the following headline: "AshStreet Reading-Room Delivered from Anarchism and Put on a Conservative Basis.” The author noted that the free reading library was under new management, having been transformed from, "a hotbed of anarchism, populism, Bryanism, social mobocracy and every other demoralizing and disturbing doctrine invented to seduce the unfortunate and ignorant and discontented into rebellion against organized government." It would now "admit no matter of which the moral tone can meet the disapproval of those citizens who contribute to the maintenance of work and who are among the leading businessmen of this community." ${ }^{.70}$ The article even named the Firebrand first in a list of several radical newspapers, including such notorious periodicals as the Socialist Labor Party's The People, the anarchist-tinged free love newspaper Lucifer the Light-bearer, and the New York based, German-language anarchist newspaper Freihiet, perhaps revealing the direct role that the Firebranders played in the radicalization of the library. This shift from more traditional, populist and reformist tendencies towards anarchism seems to follow the general trajectory of Addis' own radicalization. While Addis may have mingled with the city's progressive elite, they seemed to have inspired him to further distance himself from traditional radical and reform politics and instead embrace anarchist communism.

\section{Populism}

Addis's career as a populist politician began in 1891 when he helped to organize Portland's Citizen's Alliance, an urban precursor to the soon to be established Populist

\footnotetext{
70 "Ash-Street Reading-Room Delivered from Anarchism and Put on a Conservative Basis," Morning Oregonian, September 15, 1897, 10. This article was published two days before the first Firebrand publisher was arrested.
} 
Party. ${ }^{71}$ The national Populist Party was an agrarian reform movement most popular in the grain and cotton growing regions of the Midwest and Southern United States. The origins of the party lay in the spontaneous organization of local political action groups called Farmer's Alliances and Citizen's Alliances during the 1880s in response to the dropping price of agricultural products and anger at banks and transportation monopolies for increasingly stringent interest rates. ${ }^{72}$ Over time, these political action groups developed into powerful regional political organizations and in 1892 would unite into a single political party, known officially as the People's Party but more commonly known as the Populist Party. The Populist Party was officially formed following a national convention in Omaha, Nebraska in 1892. At the Omaha Convention, delegates from across the country adopted a platform that proposed radical solutions to the nation's many rural issues, such as the nationalization of railroads, the unlimited coinage of silver, a national income tax and the direct election of senators. ${ }^{73}$

The same year, the Oregon People's Party held its own founding convention and adopted a platform that largely mirrored the decisions made in Omaha. Oregonians had also included resolutions that dealt directly with local issues and which reflected the way in which the Populist Party in Oregon was both an urban and a rural movement. Most of the Firebrand publishers had been involved with the populist party to some degree and

\footnotetext{
71 "The Citizens' Alliance," Morning Oregonian, August 13, 1890, 2; "City News in Brief," Morning Oregonian, July 11, 1891, 5.

72 For an overview of the Populist movement and the People's Party see Lawrence Goodwyn, Democratic Promise: The Populist Moment in America (Oxford: Oxford University Press, 1976); Robert C. McMath, Jr. American Populism: A Social History 1877-1898 (New York: Hill and Wang, 1993); Gene Clanton, Populism, the Humane Preference in America 1890- 1900 (Boston: Twayne Publishers, 1991).

73 Lawrence Lipin, "Populism in Oregon," The Oregon Encyclopedia, https://oregonencyclopedia.org/articles/populism_in_oregon/\#.WUyd42jyvIU.
} 
while they ultimately rejected its political tactics, Oregon populism would significantly influence the anarchism of the Firebrand. In its platform, the Oregon People's Party targeted the railroad companies like the Northern Pacific and transportation monopolies like the Oregon Steam Navigation Company (OSNC), whose monopolization of railroad and river transportation had long been a serious financial burden for Oregon farmers, and demanded that "the government own and operate the railways. . that the Columbia river be improved and a railway parallel with that stream be run at cost by government."74 The convention also passed a resolution that dealt with the issue of land speculation by opposing corporate ownership of unused lands. The platform addressed urban concerns as well, calling for the implementation of an eight-hour work day, the elimination of private detectives in labor disputes, and the restriction of Chinese immigration, all central tenants of the Oregon labor movement. ${ }^{75}$ Sinophobia was a hallmark of radicalism in the Pacific Northwest, and the racial dimensions of the Oregon platform reflected decades of racial policies. The convention's urban proposals reflected many of the Firebrand's most significant critiques of the Portland elite, including the demand for the direct election of police and fire commissioners, which had previously been appointed positions, usually given out as political favors. ${ }^{76}$

On July 10, 1891, a meeting was held at Portland's Free Reading Room, "for the purpose of organizing a citizens' alliance."77 The Citizen's Alliance was composed of

\footnotetext{
74 "The Farmers Meet: The Peoples Party Holds its State Convention," Oregon City Enterprise, March 18, 1892, 7.

75 Boyer, "Oregon Politics and the Evolution of the Populist Movement in Portland," 125.

76 Lipin, "Populism in Oregon."

77 “The Citizens' Alliance" Morning Oregonian, August 13, 1890, 2.
} 
men and women who held occupations other than farming but who aligned politically with the tenants of the Farmers Alliance. At the July meeting, eighteen attendees joined the newly formed organization. The Committee elected Henry Addis as its President and J.H. Morrison, another future Firebrand publisher, as its Vice President. ${ }^{78}$ Addis was at the heart of this urban populist movement and, just two years after arriving in Portland, he attended the founding convention of the Oregon People's Alliance, the state's populist political party, as a delegate for Multnomah County. ${ }^{79}$ Addis would become a prominent populist in Portland, fiercely representing the party's "non-fusionist wing," and unsuccessfully running for election on multiple occasions.

Addis became increasingly frustrated with the Populist movement as it integrated into the Democratic Party under the leadership of William Jennings Bryan. Addis fought vociferously against the pro-Democrat, fusionist wing of the People's Party, and stood for election in 1896 to provide a non-fusionist populist option in the Multnomah County sheriffs election. Despite their condemnation of politics and government in generals, Addis and the Firebranders were clearly influenced by Populism, a fact that was readily admitted by its publishers, who like Addis, had been involved in the party to some degree. ${ }^{80}$

\footnotetext{
${ }^{78}$ While the Populist movement was largely a rural movement in most parts of the countries, historians have noted that the movement had a particularly strong urban following on the Pacific Slope, especially in Portland where, in 1892, nearly 40\% of the voters in Multnomah County voted for the People's Party Presidential Candidate. Boyer, "Oregon Politics and the Evolution of the Populist Movement in Portland," 17.

79 "The Farmers Meet" Oregon City Enterprise, 7.

80 "Work of Rowdies: Straight Populism Will Stick," Morning Oregonian, May 28, 1894, 8. "Henry Addis, the populist candidate for county judge, says that the fusionists have endeavored to get several of the nominees of his ticket to withdraw."
} 
Addis continued to be involved in Populist politics while writing for the Firebrand and his campaign for the Sheriff's office in 1896 took place right in the middle of the newspaper's run. ${ }^{81}$ Addis's connection to the Populist movement was so strong that historian William Haas Boyer refers to the Firebrand as Addis's "Populist/Anarchist" newspaper, in his comprehensive study of the People's Party in Oregon. ${ }^{82}$ While this description is technically incorrect, as the newspaper in no way advocated for the Populist Party or any ideology that utilized electoral politics, Boyer correctly identified the way in which the newspapers' publishers borrowed heavily from the populist platform in the development of their uniquely American anarchist philosophy.

Addis's participation in the Oregon populist movement and his experiences at the founding convention of the Oregon People's Party left a significant impression on the young radical. Even as Addis frequently rebuked the populists in the Firebrand, the influence of populist ideology, particularly regarding rural issues, can clearly be seen in his anarchist writing, in which Addis used the language of populism to illustrate anarchism's amenability to rural issues. Despite the urban focus that anarchist communism had initially taken in the United States, the movement in Europe was largely rural and especially popular amongst the peasantry of Russia, Spain, and Italy. Unlike Marx, who explicitly denied the peasantry any importance in the revolutionary movement, Bakunin and Kropotkin saw the peasantry as the group from which a

\footnotetext{
${ }^{81}$ Addis's political activities would cause considerable controversy after the collapse of the Firebrand. Both Emma Goldman and Abraham Isaak would condemn Addis for "dabbling in politics," denouncing him as a hypocrite in the anarchist press for publicly opposing politics in the Firebrand while privately participating in it for financial gains. See, "Ideas and Men," Free Society, July 10, 1898, 4-5.

${ }^{82}$ Boyer, "Oregon Politics and the Evolution of the Populist Movement in Portland," 188.
} 
revolution was most likely to occur. Bakunin cited the peasantry's long tradition of revolt in his native Russia, as well as their tendency to organize themselves into nonauthoritarian communes as evidence of their radical tendencies. ${ }^{83}$ While anarchist communists believed in communism and argued for an economy based on the notion of "from each according to his ability and to each according to his need," they believed that such a society must be organized voluntarily. They therefore did not believe in forced collectivization, arguing that farmers, living in a state of anarchism, would naturally work together and join forces. This embrace of the rural peoples, as well as the ideology's promise of no forced collectivization, meant that anarchist communism could easily be adapted to the issues facing struggling American farmers. The anarchists' argument that land ownership should be based on occupancy and use, not traditional ownership, was a central thrust of the Firebrand and the American anarchist communist movement that would develop around the newspaper. Anarchist-communism was amenable to the strife of the American farmer and the Firebranders were able to adapt the rural platform of the Oregon populist movement to the ideas of anarchist communism.

While the Firebrand remained steadfastly opposed to the political tactics of the People's Party, its contributors largely acknowledged the populist critique of local conditions. As one Firebrand contributor would put it, "[the People's Party] has done immeasurable service in pointing out the evils which beset us and to a great extent the cause thereof." ${ }^{84}$ In fact, the Firebranders discussed many of the same issues that were discussed in the Oregon People's Party's founding platform. Addis composed a

\footnotetext{
${ }^{83}$ Avrich, Anarchist Portraits, 7.

${ }^{84}$ Ezekiel Slabs, "Political Action," Firebrand, March 10, 1895, 3.
} 
particularly lengthy article titled "Anarchy and the Farmers," in which he addressed the many financial issues that local farmers faced. Unlike the socialists, who he argued would seize and redistribute farmland; the small farmer's property would be secure in an anarchist-communist society. "The Farmer of America feels the pressure of 'hard times' and is 'squeezed' by combinations of railroads, elevators and commission merchants ... unable to get cash for what he has to sell, he is compelled to mortgage his farm," Addis opined.${ }^{85}$ Addis's time with the populists provided him with a unique perspective on rural issues in the United States, an issue that other American anarchist communists had long ignored.

While the Firebranders borrowed heavily from the Oregon populist platform they could never support the Populist Party's embrace of traditional electoral politics. The Firebranders argued that the only way to enact these populist ideals was through anarchist methods: immediate revolution and the reorganization of society based on voluntary association. Addis illustrated the way in which anarchist methodology could best deal with the issues that had become the focal point of Oregon populism, "Without government, monopoly in the resources of the earth and tools of production would be impossible, and all would stand on equal footing. Association would be voluntary, and mutual interest would be the guide in all affairs in which two or more persons are concerned." ${ }^{\prime 86}$ The Firebranders argued that the immediate destruction of hierarchical government would bring a natural end to the small farmers' two primary concerns: corporate transportation monopolies and land speculation. Populists had failed to

\footnotetext{
${ }^{85}$ Henry Addis, "Anarchy and the Farmer," Firebrand, December 8, 1895, 1.

${ }^{86}$ Henry Addis, "Is Anarchism Practicable Now?," Firebrand, March 8, 1896, 1.
} 
effectively take on either of these concerns, despite winning elections and securing real political power. The anarchists had witnessed major populist victories in Oregon and Washington but argued that very little had changed for the average worker or farmer.

Even after the Populists captured a majority in both branches of the legislature in Washington State, the newly elected officials struggled to effectively implement their platform. As a result, they earned Addis's scorn, who argued that:

there is not good reason why they should not carry the program they have called so loudly for the last four years. Do they do it? Well hardly. They elected a Republican to the United States Senate, and the only populist measure they seem liable to enact is the 'dispensary' method of selling liquor, i.e. the monopolization of the liquor business by the State, Oh ye, honest populists, how long will you be fooled by self seeking politicians. ${ }^{87}$

There is no denying the degree to which the Oregon populist movement had shaped both Addis and the Firebrand.

\section{Abraham Isaak}

Abraham Isaak was born and raised in the Russian Mennonite community of Rosenthal in the heart of what is now Ukraine. It was here that Isaak first met his wife, and future fellow anarchist, Mary Dyck Isaak. ${ }^{88}$ Abe and Mary came into conflict with their deeply religious community early in their relationship after it became clear that their first child had been conceived out of wedlock. They narrowly escaped expulsion from the community for this offense but would later leave Rosenthal of their own free will and

\footnotetext{
${ }^{87}$ Firebrand, February 28, 1897, 5. See also the Firebrand's Condemnation of Washington State Governor John R Rogers, a populist who they condemned for acting like a radical while on the campaign trail but becoming a typical politician once in power. Al Klemencic "A Populist Governor," Firebrand, November 15, $1896,4$.

${ }^{88}$ Mary Isaak played a central role behind the scenes as "an unseen but necessary promoter of The Firebrand from the start, one who fed and housed us while worked on the paper." Henry Addis, "The History of The Firebrand," Firebrand, March 8, 1896, 3.
} 
settle in the city of Odessa. It was here that Abraham found work at a local bookstore and was likely first exposed to radical literature. While the exact nature of Isaak's radical beliefs during his time in Odessa are unknown, it has been suggested that he was associated with the Russian nihilist movement, most famous for its assassination of Tsar Alexander II in $1881 .{ }^{89}$ Whatever his affiliation, in 1889 Isaak was forced to flee the country to escape arrest for unspecified anti-tsarist activities. Two years later, after brief stays in Rio de Janeiro and San Francisco, Isaak joined his wife and children in Portland. Over the course of the next four years, Isaak worked hard to achieve fluency in English so that he could publish his own radical newspaper. Eventually, after finding a small community of like-minded individuals, Isaak fulfilled this personal goal with the release of the Firebrand's first issue on January $27,1895 .^{90}$

Abe and Mary Isaak were devout anarchists, and, unlike many fellow radicals, their beliefs were not just confined to the union hall or the print shop. The Isaaks practiced anarchism in their daily life, and their refusal to act as authority figures towards their three children greatly amused and inspired Emma Goldman who would later provide a detailed description of the family in her autobiography:

The particular attraction of the Isaaks for me was the consistency of their lives, the harmony between the ideas they professed and their application. The comradeship between the parents and the complete freedom of every member of the household were novel things to me. In no other anarchist family had I seen children enjoy such liberty or so independently express themselves without the slightest hindrance from their elders. It was

\footnotetext{
${ }^{89}$ Stephen Kent Smith, "Research Note: Further Notes on Abraham Isaak, Mennonite Anarchist," Mennonite Quarterly Review 80, No. 1 (2006): 83.

${ }^{90}$ An account of Isaak's early years in Portland can be found in Paul Avrich's interview with Isaak's grandson Elmer B. Isaak in "Elmer B. Isaak," interview with Paul Avrich, New York City, February 12, 1974 in Anarchist Voices: An Oral History of Anarchism in America ed. Paul Avrich (Oakland: AK Press, 2005), 2728.
} 
amusing to hear Abe and Pete, boys of sixteen and eighteen respectively, hold their father to account for some alleged infraction of principle, or criticize the propaganda value of his articles. ${ }^{91}$

Mary and Abraham also practiced free love and argued that it helped to counter patriarchal hegemony within the family, creating a more equal relationship between partners. ${ }^{92}$ Emma Goldman admitted that she was inspired by the Isaak's anarchistic family structure and would note in her autobiography that the Isaaks' championing of free love inspired her own radical sexual and gender politics. ${ }^{93}$ The Isaaks were at the very heart of the developing American anarchist movement, shaping its most defining and unique features. It is therefore interesting to note that the Isaaks were the only members of the anarchist group who came from immigrant backgrounds, with Abraham not becoming a citizen until $1899 .{ }^{94}$

While Isaak may have come to an anarchist position much earlier than the other Firebranders, he was also active in the city's local radical movement, and just like his fellow publishers, these experiences seem to have influenced his radicalism. Isaak's experiences dealing with the city's various socialist political parties and discussion groups inspired a lifelong hatred of Marxism and any other form of state socialism.

If there is one radical organization that was most detested by the Portland Anarchists, it was the Socialist Labor Party (SLP), a Marxist political organization first

\footnotetext{
${ }^{91}$ Emma Goldman, Living My Life: Volume 1 (New York: Dover Publications, 2012), 224.

${ }^{92}$ Abraham seems to have abused his free love relationship with his wife, utilizing the status of their relationship to pursue other women while, anecdotally, refusing to allow his wife to pursue a relationship with another man. This account can be found in Paul Avrich's interview with the Mary and Abraham's granddaughter Grace Urmath in "Grace Urmath," interview with Paul Avrich, New York City, February 12, 1974 in Anarchist Voices: An Oral History of Anarchism in America ed. Paul Avrich (Oakland: AK Press, 2005), 26.

${ }^{93}$ Goldman, Living My Life: Volume 1, 224.

94 "Elmer B. Isaak," Anarchist Voices: An Oral History of Anarchism in America, 28.
} 
organized in New Jersey in 1877 as the Workingmen's Party. While the party began as a fairly inclusive radical organization, by the 1890s it was defined by a narrow sectarian ideology. This ideological shift began during the 1880s when the SLP's anarchist membership broke away from the party, mirroring the larger split between Karl Marx and his anarchist rival Mikhail Bakunin in the First International. ${ }^{95}$ These events, according to labor historian Carlos Schwantes, left the SLP as "a struggling little group of less than fifteen hundred socialists." ${ }^{.96}$ The SLP began to once again expand in 1890 when the party came under the control of Daniel DeLeon, a former lawyer and professor of Latin American Diplomacy at Columbia University. While never officially elected to any leadership positions, DeLeon dominated the party through his position as the editor of the party's English language newspaper, The People.

DeLeon preached a very precise version of Marxism, often called DeLeonism, and demanded strict doctrinal obedience from his followers. While the party achieved some success in the Pacific Northwest, spreading into Oregon and Portland during the early 1890s, its dogmatic tendencies alienated many of the very people it was trying to target. As Schwantes explains, "Socialist organizations flourished in the expansive intellectual climate of the Pacific Northwest, but it is perhaps a paradox of history that the regional socialist movement eventually adopted such a narrow, sectarian ideology that it repelled more often than it attracted the rank and file workers eager to improve the new industrial society." ${ }^{97}$ Many of the Portland anarchists were former socialists and SLP

\footnotetext{
${ }^{95}$ Smith, "Further Notes on Abraham Isaak," 83.

${ }^{96}$ Schwantes, Radical Heritage, 81.

${ }^{97}$ Ibid.
} 
members and the dogmatic tendencies of the party played a major role inspiring them to turn to non-hierarchical anarchist communist philosophy.

Isaak had been one of the anarchists who broke away from the Socialist Labor Party during the late 1880 s and he would remain a fierce opponent of the political party and the state socialism it promoted throughout the rest of his life. According to Isaak's granddaughter, Grace Urmath, Isaak was so vehemently opposed to state socialism that later in life, when his son Pete became a communist the two men would have "violent arguments deep into the night, so that people on the next farm could hear them." Later, when Isaak's grandson became a communist in the 1930s, Abraham broke off correspondence with that entire branch of his family. ${ }^{98}$

It could be argued that the anarchists were even more opposed to Marxism, with its belief in the intermediary dictatorship of the proletariat, than they were to the liberalism of the late nineteenth-century United States and Europe. In the second issue of the Firebrand, Abraham Isaak, using his nom de plume "Ezekiel Slabs," attacked an editorial cartoon in The People which encouraged the downtrodden worker to join their cause by arguing that "instead of advising people to rise up in their might and smite the plute in the neck, as a fellow would naturally expect, they advise them to do what? Throw Dynamite bombs? Oh no! - vote for the Socialist Labor Party, which will eradicate these evils, which is beset us poor devils at present in the sweet bye and bye." 99 Isaak is not so

\footnotetext{
98 "Grace Urmath, interview with Paul Avrich, Anarchist Voices: An Oral History of Anarchism in America (Oakland, AK Press, 2005), 27.

${ }^{99}$ Ezekiel Slabs, "Chunks of Wisdom by the Sage of Dives' Hollow," Firebrand, February 2, 1895, 2.
} 
much arguing for terrorism, as he would later go on to clarify, but attacking the uselessness of the SLP's political tactics.

The path that Isaak took to the Firebrand and the American anarchist movement was unusual and leads to an important question, why did Isaak help establish an Englishlanguage newspaper rather than join the nation's considerably larger immigrant anarchist movement and write for one of the many German-language or Russian-language anarchist newspaper, a path that countless immigrant anarchists had taken before him? ${ }^{100}$ Even Emma Goldman, who had immigrated from Russia as a teenager, contributed to Yiddish and German language immigrant newspapers before making a name for herself within the English-speaking anarchist community. Instead, immediately upon arrival in Portland, Isaak dedicated himself to the study of the English language and sought out other radicals in his new adopted community. Isaak would eventually become one of the most important figures in the culturally American radical movement during the late nineteenth and early twentieth centuries, befriending such American luminaries as Emma Goldman, Clarence Darrow and Jane Addams. So how was it that Abraham Isaak, a Russian Mennonite immigrant who came to America understanding little to no English, would become one of the most important figures in the English language, culturally American anarchist movement? The reason for Isaak's rapid integration into American culture and radical politics is that he and his family had chosen to settle in Portland.

\footnotetext{
${ }^{100}$ As a Russian Mennonite, Isaak's first language would have been Plautdietsch, a low German dialect that developed during the sixteenth and seventeenth century and that was markedly different to the German language that was spoken during the late nineteenth century. The Mennonites were a group of German-Dutch Anabaptists who had moved from West Prussia to the Russian empire during the late eighteenth century. Isaak would later respond to correspondence in the paper in German, illustrating his ability to read and write the language. Smith, "Further Notes on Abraham Isaak," 83.
} 
Perhaps if Isaak had settled in New York, Chicago or somewhere else with a larger immigrant community, he would have simply been absorbed into the immigrant anarchist communities that existed in these cities, but in Portland, immigrant communities were much smaller and less insular, making it much more difficult to develop movements based on ethnicity. ${ }^{101}$ Instead, in Portland, Isaak found few anarchists, and those that he did find were of a decidedly different background.

Among the Firebranders, Isaak's immigrant past made him an outlier. Most of the Firebranders were born in the United States and had come to their anarchist beliefs from decidedly American experiences. Isaak's experience points to a reality of the American anarchist movement; even as the movement embraced the English language and an American cultural perspective following the foundation of the Firebrand, the movement would continue to embrace the multicultural diversity that defined the movement in the United States and across the globe. The Firebranders refused to distinguish between American and foreign-born anarchists, seeing both groups as part of American society and culture. ${ }^{102}$

\footnotetext{
${ }^{101}$ An important exception being Scandinavian socialism in the Pacific Northwest which successful organized labor and socialist organizations around ethnic communities. This was largely due to the large concentration of Scandinavian immigrants in certain Pacific Northwest Communities like Seattle and Astoria. See Paul George Hummasti, Finnish Radicals in Astoria, Oregon, 1904-1940: A Study in Immigrant Socialism (New York, Arno Press, 1979).

102 In an article written by Emma Goldman and republished in the Firebrand, concerning "The Condition of the Workers of America," Goldman repeatedly draws a distinction between the native born American worker and the foreign-born worker, drawing sharp criticism from the Firebrand publishers. Ezekiel Slabs, likely the pen name of Isaak, in a footnote to Goldman's article, counters her point that Americans can be described by their ancestry, "but they are Americans just the same, distinct in every respect from their ancestors. "The Condition of the Workers of America by Emma Goldman in The Torch, London,"

Firebrand, November 17, 1895, 3.
} 


\section{J.H. Morris}

The Firebrand never could have existed without the support of J.H. Morris. Morris was a professional printer who worked in a print shop in downtown Portland. Without access to his expertise and his equipment, the Portland anarchists would never have been able to launch their newspaper. Unfortunately, very little information about Morris exists, in part because he was absent from Portland throughout much of the Firebrand's run, attending to his chronically ill wife in Washington State. From the information available, Morris seems to have gone through a very similar process of radicalization as Addis. Like Addis, Morris was a prominent member of the populist movement, running as the People's Party's non-fusionist populist candidate for Portland Sheriff in 1894. He eventually turned away from the party and embraced anarchist communism. ${ }^{103}$ It is difficult to ascertain at what point each Firebrander began to identify as an anarchist, yet Morris and Addis moved in this direction as early as 1893 when, despite their continued participation in Populist politics, the two men started publishing the short-lived anarchist newspaper Freedom. Little is known about this precursor to the Firebrand although it seems not to have lasted a year. Perhaps the newspaper did not have the necessary local support to successfully operate, or perhaps the radical anarchist philosophy they were preaching was less appealing in the early days of the economic depression. ${ }^{104}$

\footnotetext{
103 Morning Oregonian, June 1, 1894, 8.

104 "Directory of Individuals: J.H. Morris," in Emma Goldman A Documentary History of the American Years: Volume One Made for America, 1890-1901, ed. Candace Falk (Berkeley: University of California Press, 2003), 544.
} 
The following year, Morris was elected, by a committee of Portlanders that included Addis, to the position of secretary for a newly formed labor exchange. ${ }^{105}$ The idea of a labor exchange has a long history in the anarchist movement dating back to the 1830s in the United States when it was espoused by American individualist anarchist Josiah Warren. The labor exchange dissolved sometime before the publication of the

\section{Firebrand. ${ }^{106}$}

The role of printers, the printing process and radical printing culture was a central part of the American anarchist tradition. Printing was difficult, physically taxing work. Printers worked long hours in miserable conditions, often inhaling poisonous print ink fumes. At the time, the printing process was a complex multi-stepped process that would require the printer to physically place metal blocks, each bearing a raised letter or symbol on their face, into the required order. These compositions had to be made upside-down and backwards, a difficult task to master. Once a full page was composed, letter by letter, the type was locked into place in a metal frame, called a chase, and taken to the actual press where, in the case of the Firebrand, the type would be covered with ink and physically pressed against paper by hand. ${ }^{107}$

In the United States, the printing profession had long been associated with radicalism, with printers boasting the oldest craft union in American history, the International Typographical Union which was founded in 1851. Union membership was

\footnotetext{
105 “A Labor Exchange," Morning Oregonian, April 4, 1894, 5.

106 While the exact fate of the labor exchange is unknown, Addis seems to suggest it failed in Portland because local banking institutions put pressure on the local courts to shut down the exchange. Henry Addis, "Labor Exchange" Firebrand, February 24, 1895, 6.

107 Kathy E. Ferguson, "Anarchist Printers and Presses: Material Circuits of Politics," Political Theory 42, No. 4 (2014): 396-402.
} 
essentially a requirement to work in the print trade and printers were also, as a job requirement, literate and well exposed to current events, allowing them to be more easily exposed to radical ideas. As most printing operations refused to produce anarchist publications, sympathetic printers became an essential part of the anarchist movement. As historian Kathy Ferguson puts it, "While the stock image of the bearded, black-clad, bomb-toting anarchist prevails in the public eye, a more representative figure for the classical anarchist movement would be the printer, composing stick in hand, standing in front of the type case, making and being made by material process for producing and circulating words." 108 It is very easy to overlook the physical labor involved in the publication of radical literature. Countless excerpts from the Firebrand demonstrates the degradation faced by the small group of publishers to physically set type, copy edit and print the newspapers, excluding the role they played in actually writing a great deal of the articles themselves. Having a skilled printer and access to a printing press was one of the most important factors that led to the publication of the Firebrand and the role of J.H. Morris should not be undervalued.

Through the collective physical labor of writing and printing the Firebrand, the Portland publishers would finally have the opportunity to put their anarchist principles into practice. The newspaper was organized as a free association, without a leader or a hierarchical structure. Anyone who joined the association, through participation in the publishing group or by paying for a subscription, was welcome to contribute to the newspaper. The ostracization the Firebranders felt in Portland as an intellectual minority

${ }^{108}$ Ferguson, "Anarchist Printers and Presses," 392-396. 
was the inspiration for the creation of this open platform structure. The publishers wanted their newspaper to be a center of discussion, debate, and community, not censorship: "we will not submit to the censorship of anyone, nor curtail freedom of expression that is now carried in The Firebrand. The Firebrand was started for the purpose of giving an open court, a place for the presentation of any and all opinions, on any and all subjects." 109 The Firebranders were finally breaking free from the rigid structure of the various groups and organizations that made up Portland's radical community and they wanted to share this new freedom with readers across the country. After all, as Ferguson puts it, "the papers were not simply passive vehicles for circulating ideas created elsewhere; the papers themselves were a happening of anarchism," and the Portland anarchists wanted to share this process of anarchistic creation with as many people as they possibly could. ${ }^{110}$

${ }^{109}$ The Firebrand Group, "Our Attitude," Firebrand, March 28, 1897, 5.

${ }^{110}$ Kathy E. Ferguson, "Anarchist Printers and Presses," 395. 


\section{Chapter II: Anarchism and the Myth of the West}

The anarchists are few and far between, will somebody say. Very true! And the reason is plain, because until recently the discontented could withdraw from civilization to the frontier where mutual aid and voluntary agreement was the basis of society. But the frontiers have disappeared and with it the opportunity to flee from restraint. ${ }^{111}$

Historians have long portrayed the second half of the nineteenth century as a moment of transition, a historical bridge between the premodern and the modern era in which massive interconnected structural developments, such as industrialization and urbanization, radically altered how people lived and worked. Like all radical movements of the era, anarchism developed as a response to these great changes. The Firebrand publishers and contributors were responding to the specific way in which the transformations of the nineteenth century affected American life and identity, particularly for those who lived outside of the nation's major industrial urban centers. By applying the ideas of Europe's infamous anarchist communist philosophers to local issues, the Portland anarchists presented a version of anarchist communism that was not only amenable to an American audience but that was presented as the vehicle by which Americans could fully realize the revolutionary tradition of their founding forefathers. Portland anarchists came to articulate a libertarian interpretation of the history of the American western frontier which envisioned the American west a place of political freedom and radical self-reliance, a natural anarchistic society. Of course, the anarchist's adulation of the American West was not unique.

${ }^{111}$ Ezekiel Slabs “The Great Mass," Firebrand, April 14, 1895, 2. 
For centuries Americans of all stripes had idealized the ever-shifting western frontier as a place of economic opportunity and political freedom for those white Americans able to endure the hardships of pioneering life. Oregon, in particular, was envisioned as a white promised land, a bountiful, unpopulated country, free for the taking for those willing to make the difficult trek west. Of course, the realities of western settlement were not so simplistic, as race and class were always barriers to successful western migration. Regardless, by the 1890s, Oregon had moved past its pioneer era. The transcontinental railroad had arrived a decade earlier, bringing with it an influx of migrants and capital and resulting in the rapid modernization of the region. Thus, western migrants arriving during the final decades of the nineteenth century found a region that more closely reflected the developed American East than an idyllic frontier society. For the Firebranders, anarchist communism was the means by which Americans could fully realize the western frontier utopia that had long held a place of promise in the nation's consciousness.

In both Europe and the United States, the nineteenth century was an era of remarkable change. The century saw the growth and expansion of industrial development, the emergence of the modern corporation and the development of an increasingly interconnected global economy. These changes profoundly altered the way in which Americans lived and worked as more Americans settled in urban areas and pursued employment in the growing industrial economy. According to the United States Census Bureau, in 1850 only $15.4 \%$ of Americans lived in cities. By 1900 this number 
had nearly doubled to $39.6 \% .^{112}$ The nature of American politics was shifting as well, as political machines took hold in major cities, and election rigging became standard practice. To many, the United States as it existed in the final decades of the nineteenth century was a betrayal of the idealistic principles espoused by the nation's founders and early leaders. Searching for solutions in this shifting landscape, many Americans turned to radical politics, the labor movement, and other progressive causes as a means to reform society. Anarchism was just one of many movements to gain traction in the United States during this period.

\section{Economic Opportunity in the American West}

The concept of the American West as a promised land has loomed large in American history. Since the colonial period, America's ever expanding western frontier has been envisioned as a safety valve for the more densely populated East; a place where any white American who was willing to put in the hard work necessary to settle and improve land could find economic prosperity. Oregon and the Willamette Valley, in particular, were seen as white agricultural utopias, literally described as a Garden of Eden by generations of promoters and boosters. According to historian Carlos Schwantes, exaggerated claims about the ease with which one could secure work in Oregon were printed by local boosters and promoters in publications across the United States and

\footnotetext{
112 US Census Bureau "Table 7. Population by Urban and Rural Size of Place Based on Pre-1950 Urban Definition: 1790-1950," in United States Summary: 2010: Population and Housing Unit Counts. CPH-2-1, Washington DC: U.S. Government Printing Office, 2012, 14-15.
} 
played a significant role in driving radical activity in the region as new arrivals were faced with the harsh realities of the regional economy. ${ }^{113}$

The nineteenth-century American understanding of the American West was largely shaped by the ideas of Thomas Jefferson and the Jeffersonian Democrats. Jefferson had a specific vision for the American West, in which continued westward expansion and settlement was necessary to maintain a healthy Republic. Jefferson argued that the American yeoman farmer was the ideal citizen; an American counterpoint to the European aristocracy, hardy and self-reliant and entirely removed from the corrupting influences of urban life. The yeoman farmer, with his small five-acre farm was, by Jefferson's measure, the ideal basis of a democratic society. At a time when property ownership was a requirement for citizenship and democratic participation, Jefferson understood that America needed cheap land upon which to settle and to ensure that his democratic vision for America's future triumphed over rival federalist interpretations. Jefferson argued that Americans needed more affordable land, or else American society would drift more naturally towards urbanization and ultimately aristocracy.

Jefferson's most important act to secure his vision of an agrarian democracy was the negotiation of the Louisiana Purchase in 1803. The legislative battle in congress to approve the Purchase was viciously fought, as the land treaty became a struggle between two contrasting visions of America's future, one agrarian, westward facing and dependent on a growing number of eligible voters and the other Eastward facing,

\footnotetext{
${ }^{113}$ Carlos A. Schwantes, "Protest in a Promised Land: Unemployment, Disinheritance, and the Origins of Labor Militancy in the Pacific Northwest, 1885-1886," Western Historical Quarterly 13, No. 4 (October, 1982): 380.
} 
increasingly industrial and dependent on a limited number of voters. ${ }^{114}$ Westward expansion would continue to be a core tenant of the Jeffersonian democratic platform well into the 1820 s when it was absorbed into the "manifest destiny" expansionist policies of the Jacksonian Democrats. The enactment of the Donation Land Claim Act (1850) and the Homestead Act (1862), both of which gave land to white settlers under the condition that they lived on and improved the land for a set amount of time, were clear examples of the continuing influence of the Jefferson's western policies. Even as the United States continued to expand westward during the nineteenth century, the nation was increasingly becoming more urban and more industrial. Despite the decline of America's western frontier period, the belief in the West as a white agricultural utopian society would continue to be a profoundly important ideology that shaped countless Americans' ideas about the American West. ${ }^{115}$

According to historian David Wrobel, two simultaneous placemaking phenomena took place in the American West during the late nineteenth century. The first was the overzealous promoter, often promising modern comforts and economic prosperity long before it had arrived, and the second was the over-nostalgic, aging pioneer who created mythic histories of the region's settlement period, "Those two sentiments, the hope for a post frontier past future in the West, followed later by a longing for the frontier past, have

\footnotetext{
${ }^{114}$ Barry J. Balleck, "When the Ends Justify Means: Thomas Jefferson and the Louisiana Purchase," Presidential Studies Quarterly 22, no.4 (Fall, 1992): 684-696; Steven Stoll, Larding the Earth: Soil and Society in Nineteenth Century America (New York: Hill and Wang, 2002), 69-74.

${ }^{115}$ Tamara Venit Shelton, A squatter's Republic: Land and the Politics of Monopoly in California, 1850-1900 (Berkeley: University of California Press, 2013), 6-9; William G. Robbins, "Oregon Donation Land Act," Oregon Encyclopedia, https://oregonencyclopedia.org/articles/oregon_donation_land_act/\#.Woaw HKinHIU.
} 
played an important part in the formation of western identities."116 The Firebranders and other local radicals embraced both of these phenomena as they came to Portland seeking modern economic opportunity as laborers but also desired a utopian construction of the frontier past in which society would be based on free land, economic opportunity, and self-reliance.

The Oregon Land Donation Act allowed settlers to secure free land in Oregon Country, and while early settlers would later portray themselves as ordinary American families who endured incredible hardships to establish themselves in the West, the reality was much more complicated. Despite the rags to riches narrative of the pioneer heritage movement, western migration was only available to a certain class of white Americans. ${ }^{117}$ After the completion of Portland's first transcontinental railroad connection in the early 1880s, Oregon suddenly became accessible to Americans of more moderate and lower income backgrounds, but by this time arable land was in short supply thanks in part to land speculation. Late arrivals to the region learned that much of the available unused land in the Portland area was controlled by a small group of individuals.

Over time members of the Portland business and political elite, what Portland historian Kimbark MacColl refers to as the "Portland establishment," came to control a greater amount of land in Portland and the surrounding region. ${ }^{118}$ During the 1880 s, most of the region that would become Portland, especially today's east-side suburbs, remained

\footnotetext{
${ }^{116}$ David M. Wrobel, Promised Lands: Promotion, Memory, and the Creation of the American West (Lawrence: University of Kansas Press, 2002), 1.

117 "Most Oregon settlers were plain, respectable, reasonably well educated white people of moderate circumstances." MacColl, Merchants, Money, and Power, 3.

118 MacColl, Merchants, Money, and Power, xv-xvi.
} 
undeveloped or parts of original homestead claims first settled during the 1840s and 1850s. This changed by the 1890 s, as much of this land had been acquired by prominent Portland business owners and bankers who sought to develop new neighborhoods and sell the sub-divided property lots at a considerable profit. These property owners, who were often affiliated with, or were themselves, powerful local politicians, wielded their wealth and influence to develop much of what are today Portland's inner city suburban communities through private and public investment in infrastructure, particularly the construction of bridges and the expansion of privately owned streetcar systems. ${ }^{119}$

While many came to the Pacific Northwest with utopian visions, those who had a significant say in the region's development had more traditional aspirations for the region. They looked eastward for inspiration, to growing corporate influence, greater urbanization, and greater industrial development. Environmental historian Bill Robbins argues that idealistic notions regarding the settlement of Oregon quickly dissipated amongst the region's first European American settlers once they came to understand the economic opportunity that existed within the region's bountiful landscape. "If there was any mystique associated with holding land in pursuit of some independent yeoman idea ... the actual course of events in the [Willamette] Valley suggests that in most instances such notions were quickly pushed aside in the midst of growing volume of wheat being

\footnotetext{
${ }^{119}$ A perfect example of this process was the development of Portland's Irvington neighborhood, a wealthy suburban development that was created in conjunction with the construction of the narrowgauge Portland and Vancouver Railway. The businessmen, bankers and politicians involved in the process had strong personal connections and were able to pull strings within government to ensure the success of all of their ventures. MacColl, Merchants, Money, and Power, 266.
} 
shipped down the river." ${ }^{120}$ The great natural bounty of the landscape caused reckless mismanagement of natural resources in the development of local extractive industries. The opportunity represented by the region was quickly monopolized by a small number of successful individuals, especially in the Willamette and Columbia river valleys where Portland businessmen and politicians used their immense power to take control of the region's economic potential. This meant that those who had migrated west seeking economic opportunity found themselves facing similarly difficult circumstances to what they had experienced in the East, except here they were more likely to be exploited on farms, in mines, in the forests, or in small manufacturing plants rather than in sweatshops or textile mills.

Lack of opportunity was a centerpiece of the anarchist critique of Portland and the changing Pacific Northwest. The Firebranders saw Portland as a lush and productive landscape, with enormous economic potential. They were therefore frustrated by the egregious levels of poverty and homelessness that existed within the city. This frustration was fueled by the long-engrained belief that the American West was supposed to be a place of widespread economic opportunity, of cheap land and self-reliance. The anger that many Pacific Northwest migrants felt after discovering the true lack of opportunity that existed in the rapidly developing region, is described by historian Carlos Schwantes as "disinheritance," a belief that land and opportunity in the West was supposed to be their birthright as Americans but had been denied to them due to the unfair monopolization of land and extractive industries. Schwantes argues that the concept of

\footnotetext{
${ }^{120}$ William Robbins, Landscapes of Promise: The Oregon Story, 1800-1940 (Seattle: University of Washington Press, 1997), 105.
} 
disinheritance was actively promoted by local labor agitators to drum up support for their causes, particularly the anti-Chinese labor movement of the 1880s: "They often voiced an unmistakable fear that monopoly unfairly threatened the political egalitarianism and economic opportunity that they believed was the birthright of American settler in the West." 121 The Firebranders frequently used this language of disinheritance to support their anarchist platform. In an early Firebrand article discussing a local Fourth of July celebration, one of the Portland anarchists argued that a procession of "disinherited, men women and children" should carry a banner through the city on Independence Day that read "WE ARE THE DISINHERITED, NO LANDS, NO HOME, NO MONEY, WE ARE NOT IN THE RING," and that "if the Spirit of '76 is in you, you will come out on independence day, and show it." 122 The ring to which the author referred was the Portland establishment and the Firebranders frequently referred to the city's political and business leadership by this name. The article's author blamed the city's elites for the landlessness, homelessness and poverty that impacted the city's lower classes, arguing that they were denying many Portlanders their birthright.

Like many Americans, the Portland anarchists idealized the American frontier as a paradise lost where the potential for an agricultural utopian society had been ruined by the encroachment of land speculators and the incursion of corrupt government. While the realities of life in Portland and the Pacific Northwest were disappointing for many migrants, to the anarchists they represented the corruption of a naturalistic anarchist society. "There is not a portion of the United States, except the original colonies, where at

${ }^{121}$ Schwantes, "Protest in a Promised Land," 373-390.

122 "The 4 Of July," Firebrand, June 23, 1895, 2. 
some time, there was absolutely no governmental interference of any kind on land holding, use being the recognized title," one of the Firebranders lamented. "This time is referred to by old men as the "the good old days when nobody suffered from want.""123 The Firebranders frequently argued that much of the West had been settled organically, without any government interference.

In one early article, Henry Addis wrote about oyster growers on Shoalwater Bay, Washington who had taken possession of the tide flats without an official government title. "No title could be obtained to the flats, so the people simply staked off such portion as they severally wanted for their own use. The fact of occupancy and use was recognized as title enough so all lived and worked on these terms of equality." ${ }^{124}$ According to Addis, oyster farmers established a stable, unregulated society without any external direction, but eventually the government sought greater tax revenue and surveyed the land, dividing it into lots. Those who had long lived and worked the tide flats suddenly found they had to pay for the land they occupied. "Once the state took cognizance of their existence, the necessity for tribute paying began, the opportunity for making a living narrowed and the old story repeated. Government never has been anything but robbery and murder." 125 Addis utilizes the story of the Shoalwater Bay squatters to suggest that if land ownership was based on occupancy rather than legal ownership, the myth of the western frontier could be actualized. What Addis does not mention in his account of Shoalwater Bay is that by illegally occupying these plots, the squatters were denying

123 “A Sample," Firebrand, September 22, 1895, 3-4.

124 Ibid.

125 Ibid. 
Native Americans, who had legal rights to occupancy and resource use. Like many nineteenth century American settlers, the Shoalwater Bay oyster farmers were squatting to circumvent land treaties and illegally occupy Native Peoples' land. Addis's unwillingness to discuss the racial components of the Shoalwater Bay squatting incident is indicative of the Firebranders general unwillingness to grapple with the realities of racial inequality in post-reconstruction America and alludes to that the fact that the American perspective of the Firebrand was very much shaped by the whiteness of its publishers. ${ }^{126}$

The Firebranders also frequently expressed frustration that there were countless acres of land in the Portland area that went unworked when there were so many unemployed and underemployed men and women in the city desperately looking for employment and sustenance. In an early issue of the Firebrand, a Portlander, writing under the moniker of "Plato of Portland," produced a scathing indictment of Portland's elite, arguing their strict ownership over productive land in the city was denying impoverished Portlanders of the right to work: "There is any amount of Vacant land in and around the city. If put to use it would sustain the lives of these starving people. They are idle; so is the land. The idle people and the idle land cannot come together, for the land lord stands between them. He stands between them and their children's bread."127 The writer placed the blame for the suffering of Portland's impoverished squarely on land speculation by the city's elite, arguing that if Portlanders were allowed to work the city's

\footnotetext{
${ }^{126}$ For an overview of the racial dimensions of squatting in the American West, see Shelton, $A$ Squatters Republic, 7-18. 127 "One Turn of the Wheel," Firebrand, April 4, 1895, 2.
} 
unused land, rampant poverty could be brought under control. According to the anarchists, the city's growing transient population was the result of clear mismanagement of land and natural resources caused by an inefficient economic system and they argued that through the enactment of an anarchist communist system, the American West would once again be a land of opportunity. Opposition to land speculation was an important part of the Firebrand's local platform and reveals how the content of the paper was very much influenced by local issues.

\section{Consolidation of Political and Economic Power}

Local government in Portland had changed considerably since European American settlers had first arrived in the region during the 1840s and 1850s, but throughout most of this time, political power had largely been monopolized by a small number of powerful businessmen and property owners. William Ladd, Benjamin Holladay, Henry Corbett, Simeon Reed, Josiah Failing, Frank Dekum, and John C. Ainsworth; the names of these men should be familiar to anyone who has spent much time in Portland as many of the city's streets, buildings, parks, and neighborhoods today bear their names. Through a shrewd mixture of business and political tactics, these early Portland leaders overcame the numerous regional rivals that dotted the Willamette and Columbia rivers and established Portland as the Pacific Northwest's principle city, the port of choice for the region's farmlands and extractive industries. While these men are rightly credited for the early development of Portland, the aggressive tactics that they used to achieve these means were often self-serving and were only possible due to a long intact marriage between private industry and political power. This relationship frequently crossed the thin line between what was simply unethical and what was illegal. Those who 
still yearned for an agricultural utopia in Portland and the Willamette Valley, were outraged by the way in which the Portland elite wielded local political power to protect their economic stranglehold over regional transportation, land prices, and industry. While some may have seen Oregon as an idealized frontier in which they could escape the stranglehold of Eastern industrial society, Portland's early leaders wanted to create a modern industrial powerhouse on the Willamette and Columbia.

The Portland establishment first took hold during the 1850s, with its earliest prominent leaders coming from a group of wealthy merchants who operated warehouses on Portland's Front Street along the western bank of the Willamette. These pioneering merchants first found success following the San Francisco Gold Rush of 1849, when they made small fortunes shipping supplies south to the rapidly developing Bay Area. The merchants' success during the Gold Rush proved the profitability of the Pacific Northwest, generating an influx of eastern capital into the region. ${ }^{128}$ Henry Corbett, Josiah Failing, and William Ladd, some of Portland's most enduring politicians and businessmen, were all members of this early group. These men first began to hold of the city's political system during the early 1850 s, when they began to secure political offices and challenge the small group of local property owners who had controlled the city since its founding. The merchants had consolidated their political power by the end of the decade. ${ }^{129}$

\footnotetext{
${ }^{128}$ MacColl, Merchants, Money, and Power, 28.

$129 \mathrm{lbid}, 51-53$.
} 
During the 1860s and 1870s, the Portland establishment monopolized trade up and down both the Willamette and Columbia river. New discoveries of gold and other precious metals throughout the Pacific Northwest, particularly in Idaho, Montana, British Columbia and along the Columbia River, would prove to be a significant boon for the regional economy. Due to its geographic location at the confluence of the Willamette and Columbia rivers, the growing city was ideally located to reap the rewards of this new interior growth. Under the auspices of the Oregon Steam and Navigation Company (OSNC), The Portland establishment monopolized control of traffic on the region's rivers through the construction of portage railroads alongside unnavigable portions of the rivers, such as the Celio falls on the Columbia and Willamette Falls on the Willamette. ${ }^{130}$ The business venture eventually expanded westward, where they operated fleets of steamships and numerous portage railroads, canals and locks as far as the Snake River and the headwaters of the Missouri River. ${ }^{131}$ The growth of the OSNC, the enrichment of its investors, and the development of Portland were all interconnected. While Portlanders reaped the benefit of this trade monopoly and the goods it directed towards the city, the OSNC was also greatly detested by the miners, loggers and farmers who relied on the network and were forced to pay the OSNC's fees. As Carl Abbott put it: "Through the OSNC, pioneers and prospectors indirectly paid for the growth of Portland by generating the fortunes that Ladd, Ainsworth, Reed and their colleagues invested in the city's

\footnotetext{
${ }_{130}$ MacColl, Merchants, Money, and Power, 122-123.

${ }^{131}$ Abbott, Portland in Three Centuries, 36. The OSNC's Portland investors would become enormously wealthy and would help drive the city's economy forward through their continued local investments. OSNC investors would remain prominent members of the Portland elite for decades to come and included John C. Ainsworth, Simeon Reed, the founder of Reed College, and William S. Ladd, the fifth and eighth mayor of Portland.
} 
factories utilities and real estate." ${ }^{" 132}$ Resentment towards the Portland establishment's economic stranglehold over the regional economy drove radicalism throughout the nineteenth century.

By the 1870 s and 1880 s, the city's elite turned their attention to the development of regional railroad lines. A transcontinental connection was the ultimate objective, but members of the Portland establishment had been engaged in fierce rail building projects well before the city made its first transcontinental connection in 1881. During the late 1860s and early 1870s two Portland companies, The Oregon Central Railway Company backed by Simeon Reed, Henry Corbett, and William Ladd, and the Oregon and California Railroad Company which was owned by rail magnate and Portland newcomer Ben Holladay, held competing railway lines on opposing sides of the Willamette. Each company sought to connect Portland to California and engaged in a bitter bidding war to gain access to the federal right of way. In the end, Holladay won the grant, his opponents claimed he had bribed the state legislature, and then proceeded to build a "tottering transportation empire" in Portland. ${ }^{133}$

Portland's early pioneer millionaires continued to dominate local government, often using their political powers to aid their business pursuits. Out of Portland's thirty wealthiest citizens in 1870, ten held public office from 1853 to 1859 and seventeen held at least one political office from 1860 through $1877 .{ }^{134}$ The men involved in the OSNC transportation monopoly were no exception. William S. Ladd served two non-consecutive

\footnotetext{
${ }^{132}$ Abbott, Portland In Three Centuries, 36.

133 Ibid, 39.

${ }^{134}$ MacColl, Merchants, Money, and Power, 163.
} 
terms as mayor during the 1850s and Henry Corbett was Oregon's United States Senator from 1867 to 1873 and would play a prominent role in the Oregon Republican Party until his death in 1903. ${ }^{135}$ These men may have propelled Portland into the future, but many felt that they did so through extralegal means and at the expense of the city's growing working class.

Portland's great business men, politicians, and boosters, often one in the same, spent decades working to outwit regional rivals, to make Portland the center of commerce and trade on both the Willamette and Columbia Rivers. They envisioned the city as the great commercial and industrial heart of the Pacific Northwest, a new Chicago in one of the nation's last frontiers. Portland's early leaders embraced the great transformations of the nineteenth century and utilized industrialization, the corporate monopolization of infrastructure and natural resources, and often questionable political tactics to drag Portland out of the mud and place themselves at the top of the local hierarchy.

Many of those who had come to the Portland area seeking economic opportunity and political freedom were frustrated by the city's leadership. Some of them turned to local radical and reform movements that developed during the final decades of the nineteenth century to challenge the political and economic establishment. Anarchists, with their absolute rejection of government, held the most unflinching critique of the local establishment and most strongly resented the ways in which local elites had directed the city's development. The Firebranders idealized the American West as a place of political and economic freedom but in Portland found an overbearing government

${ }^{135}$ For an in-depth discussion of the Portland establishment's involvement in politics see, MacColl, Merchants, Money, and Power, 65-71. 
dominated by a small group of enormously wealthy elites who they believed controlled every aspect of the community's development. The Firebranders frequently pointed to local political events and scandals as evidence of the irreformability of government and the pointlessness of electoral politics.

Anarchist critiques of local politics, both its major scandals and its perceived general inefficiencies, were characteristic of the Firebrand during its first three months in publication. The newspaper had yet to develop a national audience or a significant number of contributors and thus the newspaper focused heavily on local issues during this period. In these early articles, the Firebranders utilized the scandals and corruption of the city's elite to argue for the reformation of society based on anarchist communist principles.

The Firebrand publishers had a particularly strong dislike of the local Republican Party and its mouthpiece, the Oregonian. ${ }^{136}$ The Republicans held a virtual monopoly of political power in Portland and Oregon during the 1880s and 1890s, with a few notable exceptions. The Democratic Party was notoriously weak in Oregon and many elections in the state were simply competitions between rival Republicans. While there were rival factions within the Oregon Republican Party, the Firebranders were most concerned with what they referred to as the Simon-Corbett ring, one of two powerful factions that was vying for control of the local political system. The faction was led by the powerful lawyer Joe Simon and pioneer merchant, banker, and businessman Henry Corbett. While Joe

\footnotetext{
${ }^{136}$ Portland based Firebrand contributor John Pawsons referred to the Oregonian as "the leading monarchist mouthpiece on the Pacific Coast." See, John Pawsons, "The Babbling Mob of Aristocracy," Firebrand, February 3, 1895, 3-4.
} 
Simon and Henry Corbett were central players, the ring went back decades and included many of the city's most prominent citizens. According to MacColl, Simon was "the most powerful individual in Oregon's politics from 1880 to $1910 . " 137$ The Firebranders took on the Simon-Corbett Ring early in its publication, attacking the political machine in their first issue. The Portland publishers released a series of articles criticizing the ring's efforts to pass a new city charter that they worried would make city government less accountable by placing it more firmly under the control of the Simon political ring. This issue symbolized everything the anarchists despised about Portland politics: political corruption, the influence of big business on legislation, and the elitism of the local press. The anarchists argued that the proposed city charter was the perfect example of how government, even democratic government, was irreformable.

Simon and his allies presented the proposed charter as a cost saving measure, because it would reduce the salaries of many public officials, including the mayor and city council. The charter would also have established a Board of Public Works, which would control "the police, fire, street, park and other executive departments." ${ }^{138}$ In the proposed charter, the Committee of One Hundred, made up of Portland's most powerful and wealthy citizens, would appoint the Board of Public Work's membership. The Simon-Corbett ring dominated the Committee of One Hundred, with Henry Corbett presiding over the committee. ${ }^{139}$ Ultimately, the proposed city charter faced significant

\footnotetext{
${ }^{137}$ MacColl, Merchants, Money, and Power, 244.

138 Sunday Oregonian, January 13, 1895. 6.

139 This was only one of many political power grabs made by the Simon group, and Joe Simon himself had already used similar methods to establish and then control both the local Water Board and Police Board in the previous decade. Simon's takeover of the police force was particularly effective as it allowed him to utilize the local police to protect the saloons, liquor wholesalers, and gambling establishments that were
} 
opposition, in part due to the activities of the Firebranders and their fellow radicals. Portland's People's Party, which was at the height of its popularity, had multiple representatives serving on the City Council who, after considerable public shaming, voted against the charter. ${ }^{140}$ Members of the Firebrand played a prominent role in the opposition to the new charter, particularly by using their newspaper to attack local politicians who had campaigned on political reform, like the Populists, but who were not vocally opposing this latest power grab.

Mary E. Squires began the Firebrand's six issue assault on the Simon-Corbett charter in the newspaper's very first issue. Her anger at Portland's political, journalistic, and business practices were expressed explicitly:

Muzzle the press, and freedom dies. We have reason to believe that every press in Portland is either partially or wholly muzzled. What better evidence could we wish for than that Joe Simon dared to make a new city charter and refused to haved [sic] it inspected, and that not one of our great daily papers make any comment, and that $\mathrm{Mr}$. Corbett, the chairman of the 'committee of one-hundred,' indorsed [sic] such a crime against the people. This should be evidence that Corbett is the Tallyrand and Simon the Napoleon; or in other words, that Corbett makes the bullets while Simon fires them. ${ }^{141}$

Squires then quoted Patrick Henry's famous "give me liberty or death" speech and then called on the people to rise up against the charter. Six issues later, in her final article on the issue, Squires cautiously praised the populist politicians who stood their ground and defeated the bill. Using her characteristically dramatic prose, Squires declared that the level of corruption Populists faced in "those

\footnotetext{
owned by himself and his compatriots while simultaneously shaking down rival establishments. MacColl, Merchants, Money, and Power, 245.

140 "Simon-Corbett Charter," Firebrand, February 24, 1895.

141 "Simon-Corbett Charter," Firebrand, January 27, 1895.
} 
legislative halls of state and nation" was worse "than the old fashioned hell of fire and brimstone, and the man who can pass through them and come out with right against might — the almighty dollar—is an almighty man." ${ }^{142}$ Squire's SimonCorbett articles reveals how the Firebranders' could apply the principles of anarchist communism to local issues. The articles targeted local readers and presented a powerful critique of the usefulness of local political institutions. ${ }^{143}$

Political corruption was rampant in Portland during the late nineteenth century. Just like Chicago, New York, or any other major American city, Portland politics was largely defined by political machines and election rigging. Vote buying was particularly common practice, largely taking place in Portland's impoverished, vice-ridden North End. Political bosses controlled vice activities in the region and, for a large enough sum, could whip up thousands of votes for a candidate. Bosses would empty out sailors' boarding houses, saloons, and other vice establishments then pay, or coerce, its denizens to vote for certain candidates. Many of these individuals were not even residents of the city. It was hard to hide such activities from the general population, and everyone in Portland knew that elections could be purchased. It is no wonder that some Portland radicals had become so distrustful of the local political system. ${ }^{144}$

\footnotetext{
142 "Simon-Corbett Charter," Firebrand, January 27, 1895.

${ }^{143}$ Almost no context was given regarding the background of the Simon-Corbett affair. It would have been next to impossible to understand the newspaper's articles about the charter if one was not a wellinformed Portlander. This reveals that the publishers assumed most of their readers were from the local area during the newspapers first few weeks in operation.

${ }^{144} J$ ewel Lansing, Portland: People, Politics, and Power, 1851-2001 (Corvallis, Oregon State University Press, 2003), 214-215.
} 
Anarchists had become so disenchanted with Portland's political system they even interpreted political victories as proof of the irreformability of government. For example, when Joseph Dolph, a prominent Portland politician and core member of the Simon ring, failed to be reelected to the United States Senate, Addis argued that this did not reflect a popular dismissal of a corrupt establishment figure, but instead was a part of the establishment's masterplan. According to Addis, the defeat was preordained by the local political establishment and only took place to give Oregonians an illusionary sense of control over their government. "When $\mathrm{D}[\mathrm{olph}]$ was finally defeated then some of the poor foolish persons who had worked so vehemently against him actually imagined they had 'influenced' the choice. That is what the 'powers to be' wanted." 145 While Addis' argument seems conspiratorial, the power that the Simon wing of the Oregon Republican Party held over the fate of elections was quite impressive. According to MacColl, Addis was at least correct to suspect foul play in the senatorial election as railroad magnate Henry Villard and the Northern Pacific Railroad attempted to purchase the election for Dolph, spending an astounding $\$ 300,000$ on the campaign. Jonathon Bourne, another wealthy businessman and important political player, later admitted to spending $\$ 10,000$ on Dolph's opponent's campaign. ${ }^{146}$ Though Dolph may have spent the most money bribing state legislators, he still lost the election. Regardless, the election illuminated the high levels of corruption that existed in local politics and the way in which local elections were clearly manipulated by the city's wealthy elite, who used their fortune and political connections to ensure that their interests were secure.

\footnotetext{
145 Addis, "How It is Done."

146 MacColl, Merchants, Money, and Power, 322.
} 
The core Firebrand contributors found elections to be pointless and criticized any radical group who sought change through the ballot box, no matter how closely they aligned on other issues. Countless articles and editorials expounded upon the worthlessness of the ballot and the need for immediate revolution. While this absolute rejection of government must have seemed alien and un-American to most locals, the Firebranders came to this conclusion not just from exposure to anarchist communist ideology but also as a result of their disillusionment with the local political system. According to Addis, "clear thinking people know full well that popular government, like all other forms of government, is the relentless foe of liberty and must live up to our highest ideals. ${ }^{147}$ In a city, in which vote buying was notoriously common and political corruption was standard practice, it is understandable why the anarchists disparaged the vote with such ferocity.

The Portland anarchists were furious at the lack of economic opportunity and political freedom that they found in the American West, the supposed safety valve of the nation. The corruption that the Firebranders witnessed at the hands of Portland's political and business establishment affirmed their belief in anarchist anti-statist principles and provided them a target with which they could hone their larger critique of American society. Through their engagement with local issues during the newspaper's first three months, the Firebrand developed a more general critique of American society that would become a centerpiece of the culturally American anarchist platform for the next two decades.

${ }^{147}$ Henry Addis, “Popular Government," Firebrand, April 4, 1895, 1. 


\section{Chapter III: The Growth of the Firebrand and the Development of a Culturally American Anarchist Voice}

On March 8, 1896, just over a year after the release of its first issue, the Firebranders published an article titled "The History of the Firebrand." This article detailed the Firebrand's first year in publication and revealed that the newspaper had significantly expanded its readership and attained a place of prominence within the national anarchist movement. The small band of unknown Portland anarchists had established the first truly successful English language anarchist communist newspaper in the United States and thus created a space for culturally American radicals to discuss anarchism and build community. American anarchist-communists had long bemoaned the fact that they were unable to make any significant gains outside of urban immigrant communities and were therefore encouraged by the progress made by the Portland upstart. Not only did the movement finally have a thriving English language publication but it also had a new community of activists who could advocate on behalf of the movement amongst the long unreceptive non-immigrant American population. ${ }^{148}$ The newspaper's adoption of an open platform model, that allowed readers to feel like active members of a community rather than passive consumers of propaganda, and its use of a culturally American perspective, allowed the newspaper to connect to a wide swath of English speaking Americans.

According to the Firebranders, the newspaper's initial readership was the result of persistent propaganda efforts on the part of the publishers and a few key regional

\footnotetext{
${ }^{148}$ Addis, "This History of The Firebrand," March 8, 1896, 3.
} 
supporters in Portland and Western Washington. The newspaper therefore had a largely regional readership during its first three month in publication. In Portland, the Firebrand publishers distributed the newspaper to various personal acquaintances and sympathetic local radicals. They also sold copies of the newspaper on the street. ${ }^{149}$ These early Portland readers were often heavily critical of the newspaper's perspective, with many readers writing in to oppose the Firebrand's anarchist take on local issues. It should be noted that the newspaper's readership from Portland quickly dissipated. In Washington, the newspaper gained a strong early following through the efforts of the Tacoma based tailor Al Klemencic, who purchased issues in bulk and distributed them to his clients and to various local radicals. Addis also made propaganda trips through the State of Washington, in which he gave speeches in support of anarchism and gathered subscribers for the paper. ${ }^{150}$

Evidence to support the Firebrand's depiction of the newspaper's early growth can be found in its "Letter-Box" column. The column was published each week and contained brief answers from the publishers to specific questions sent in to the newspaper by readers. The Letter Box column usually dealt with clerical issues like address changes or donations to the paper's propaganda fund and was created to save money on postage. What is significant about this section is not the responses themselves, but the fact that the Firebranders also had to state the names and locations of each person to whom they were

\footnotetext{
${ }^{149}$ The Firebrand publishers described their local propaganda efforts thusly: "In Portland the propaganda is progressing as rapidly as could be expected. Street meetings are held three times a week, comrades Squire and Addis speaking and selling the Firebrand." Quote taken from "The Propaganda," Firebrand, July 14, 1895, 4; Henry Addis, "Free Speech," Firebrand, June 9, 1895, 1.

150 Henry Addis, "Radicalism in Tacoma," Firebrand, April 21, 1895, 4; Henry Addis, "The Work of Propaganda," June 2, 1895, 3.
} 
responding. Thus, the Letter Box column provides a sample from which one can draw certain conclusions about the Firebrand's readership. The Letter Box column first appeared in the paper's fifth issue, on February 24, 1895. The location of the readers mentioned in the Letter Box reflects the local focus of the newspaper's content during its first three months of publication as it contained responses to two readers from Portland, one from Seattle, one from an undisclosed location, and one from the city of Minneapolis. ${ }^{151}$ An analysis of the Letter Box column over the next several issues, continues to reflect the newspaper's early regional readership and even reflected Addis and Klemencic's propaganda efforts in Washington as an increasing number of the readers mentioned in the column were from communities in that state.

Roughly three months into the newspaper's publication, the reader locations from the Letter Box column began to include more places outside of Oregon and Washington, thus supporting the Firebranders claims of their newspapers growing national importance. For example, in its August 11, 1895 issue, the Letter Box addressed readers from a diverse set of locations, including: Summerland, California, Lopez, Washington, Los Angeles, California, and London, England. ${ }^{152}$ The publishers attributed the Firebrand's popularization outside of Oregon and Washington to the way in which they had enlisted several prominent anarchist intellectuals and activists to write for the newspaper. These figures included Lucy Parsons, Lizzie and William Holmes, and William C. Owen, all of whom had been significant figures in Chicago's Haymarket-era anarchist movement. The weight of these names likely helped draw readers to the

151 "The Letter-Box," Firebrand, February 24, 1895, 4. 152 "The Letter-Box," Firebrand, August 11, 1895, 4. 
Firebrand but the rapid way in which the newspaper expanded its readership suggests that these famous anarchists were doing more for the newspaper than just contributing articles. Around the time that the newspaper started to gain a national audience, the Firebranders started to frequently to publish notices stating that they had sent out "sample copies and complementaries" to potentially sympathetic persons and then asked these new readers to subscribe to the paper. ${ }^{153}$ The publisher never explicitly stated where they had gotten these names and addresses but anarchist historian William Reichert suggests that these names were likely taken from the readership lists of The Alarm, the English language mouthpiece of Chicago's anarchist-leaning IWPA during the 1880s. ${ }^{154}$ Lucy Parsons, Lizzie Holmes, and William Homes had all been involved in the publication of The Alarm, and according to Reichert, there was a significant overlap between those who contributed to the Firebrand and those who had contributed to the Alarm. ${ }^{155}$

Despite its growing success, the newspaper was on precarious financial footing and at risk of collapse due to the sheer exhaustion of the publishers. The Firebranders, true to their anti-capitalist beliefs, rarely enforced their paper's price and frequently continued to send issues to readers who were behind on their payments. ${ }^{156}$ Thus, the newspaper barely received enough funds to operate. To keep the newspaper in print, the core publishers threw themselves into the support of the newspaper, devoting what little time and money they had towards their small publication. Worse, the Firebrand group

\footnotetext{
${ }^{153}$ An early example of this type of notification can be found in Firebrand, June 30, 1895, 3.

154 Reichhert, Partisans of Freedom, 265-266.

155 Ibid.

156 In a later article Addis bemoans his readers "If as many as two thirds of these who have subscribed would pay their subscriptions we would not be under the necessity of borrowing from the press fund." Henry Addis, “One Year's Experience," The Firebrand, January 10, 1897.
} 
was bleeding members. Henry Addis alerted the newspaper's readers that members of the group had "dropped out one by one until comrade Isaak's family and I are all that are left." ${ }^{157}$ Despite acquiring a growing national readership, the movement was weak at the local level. As previously discussed, there were only a handful of actual anarchists in the Portland area and by the newspaper's first anniversary few Portlanders were mentioned in the Letter Box column. The publishers' maltreatment at the hands of the local radical community had driven the Portland anarchists to create the Firebrand where they established an open platform to be utilized by themselves and similarly isolated radicals across the nation. The Portland anarchists' devotion to the newspaper's open platform model allowed fellow isolated radicals from across the country to find community on the pages of the Firebrand.

As the Firebrand's readership began to expand beyond its initial regional audience, the newspaper shifted its focus away from local issues and embraced its role as the intellectual center of the culturally American anarchist communist movement. In this capacity, the newspaper had three primary functions. First, the newspaper acted as a community hub for a dispersed group of radicals, thinly spread across the entirety of the United States. The newspaper fulfilled this function through the adoption of an open platform structure, in which the Firebranders published contributions and correspondence from anarchists across the country, encouraging discussion and the building of community. ${ }^{158}$ The second function of the newspaper was to introduce the ideas of

\footnotetext{
${ }^{157}$ Addis, "The History of The Firebrand," 3.

158 While the publishers clearly could not publish every entry they received, and clearly shaped the conversations that took place in the newspaper through their ability to choose what to contributions to
} 
anarchist communism to an American audience. In this capacity, the Portland publishers released long form articles about political and economic theory, typically written by the publishers themselves or taken from the works of anarchism's most famous philosophers. ${ }^{159}$ The publishers then encouraged readers to discuss the articles and frequently published reader responses to the original articles. The third function of the Firebrand was to encourage the discussion of issues outside of political and economic theory and to discuss the ways in which anarchist principles could be applied to such topics. Free love and women's rights were the most popular of these tangential subjects but other topics, such as education, religion, and the Spanish-American War, were also frequently discussed. Earlier attempts had been made to publish English language anarchist communist newspapers in the United States but none of them effectively spoke to American audiences. ${ }^{160}$ The Firebrand distinguished itself through an expression of working class American identity by taking the ideas of the larger international anarchist movement and filtering them through American culture and history, creating a new, culturally American expression of anarchist communism.

\footnotetext{
print, what is important is that the newspaper portrayed itself as a space of open conversation and that its readers agreed.

${ }^{159}$ For a more in-depth discussion of the political and economic perspective of the Firebrand and its key publishers see Reichert, Partisans of Freedom", 261-265.

${ }^{160}$ Earlier anarchist communist newspapers included Boston's The Rebel and New York's Solidarity. These newspapers focused heavily on political and economic theory and almost exclusively printed the works of the movements most well-known figures. This strategy proved to be less appealing than the Firebrand's grass roots, community-centric approach, as both newspapers ultimately floundered due to lack of support.
} 


\section{The Anarchist Communist Interpretation of American History}

One of the most blatant ways this Americanization was expressed was through references to American history. The Firebranders did not need to turn to Europe for its heroes, American history had an abundance of figures for the anarchists to hold up as models of libertarianism. Whether it be the abolitionist struggle against slavery, the free thought movement's rebuke of religiosity or even the founding fathers' fight to establish an independent United States, the Firebrand embraced a unique American cultural identity that was based on an anarchistic interpretation of American history.

The anarchist communist interpretation of American history, as expressed in the Firebrand and its successors, focused heavily on the legacy of the American Revolution. The anarchists found that the United States' foundational struggle against the British Empire and their own struggle against the state to be comparable. The anarchists did look further back in American history for inspiration, taking particular interest in pre-contact Native American history. While the Firebranders rarely dealt with issues of race and racism in the United States they did, on occasion, condemn the United States' historical treatment of Native Americans and celebrated Native communities' traditional practice of communal land ownership. The anarchists' characterization of Native Americans was largely based on over simplistic stereotypes. Most anarchists were Rousseauian in their understanding of prehistory, arguing that humans naturally lived in a state of total freedom. According to most anarchists, modern society had forced people away from this state of freedom and into coercive, authoritarian systems, but through the implementation of anarchist philosophical principles, society could return to this enviable natural state of freedom. For the anarchist communists, communal land ownership was viewed as being 
the natural state of affairs for human society. ${ }^{161}$ Therefore, anarchist communists frequently pointed to supposedly primitive societies' communal structure, real or imagined, as evidence of the rightness of communal organization.

In Russia, anarchist philosophers Peter Kropotkin and Mikhail Bakunin both held up the Russian peasantry's practice of communal land ownership as evidence that humans naturally organized themselves collectively. ${ }^{162}$ The Firebranders used oversimplified ideas about Native American economic structures to put their own American spin on this argument. For example, in the Firebrand's second issue, one contributor referenced the supposed communal principles of Native American, who he characterized as having existed in a state of nature before the arrival of Europeans settlers, to argue that communal organization was something that all humans intrinsically understood. "It is only by gradual evolutions that man has submitted to government, to be ruled by his fellow man," argued Slabs, "The Indians of our own country are fiercely resisting separate ownership. The five civilized tribes of Indian Territory, although they have adopted all other ways of the whites, still cling to common ownership of Mother Earth, the land." 163

The Firebranders also frequently celebrated colonial religious dissenters, highlighting their rebelliousness while ignoring most other aspects of the dissenters' beliefs and actions. Henry Addis and Abner Pope traced their heritage back to Quaker descendants in colonial New England and often compared the persecution their ancestors

\footnotetext{
161 Sonn, Anarchism, 29-30.

162 Ibid, 3-4.

${ }^{163}$ Ezekiel Slabs, "Chunks of Wisdom by the Sage of Dives Hollow," Firebrand, February 3, 1895, 1.
} 
faced to the persecution they faced as radical anarchists. After being arrested for the publication of the Firebrand, a writer for the Oregonian recounted Pope telling him that "his ancestors had lain in jail and died there by hundreds for their opinions, and then spoke of the persecution of the Quakers in early days in New England, and how Mary Dyer had been whipped and branded on the tongue for being a Quaker." ${ }^{164}$ Despite their opposition to the economic and political structure of the United States, the Americanborn Firebranders were deeply proud of their American ancestry and used it to defend their anarchist ideology. Far off contributors followed suit, placing their own ancestors into similar narratives. W.P. Borland of Bay City, Michigan contributed an article that placed the early pre-revolutionary settlers of West Virginia into an anarchist ancestry, noting that they had naturally formed an anarchistic society. He wrote, "Here was a community of people — emigrants from the old world — who had been bred under the aegis of authority, whose hereditary instincts must have been all in favor of government outside themselves and to whom democracy even could have been no more than a mere tradition, falling naturally and easily into an orderly society, and maintain a rigid social code from which all vestige of law and government was absent" ${ }^{165}$ Anarchists and sympathetic radicals from across the country were participating in the creation of this new Americentric anarchist interpretation of American history, often looking to their ancestry for inspiration.

The Firebranders were particularly infatuated with America's revolutionary period, frequently taking the arguments made by the colonists against British rule and

\footnotetext{
164 "An anarchists in Jail," Morning Oregonian, September 18, 1897, 10.

165 W.P. Borland, "Historic Evidence," Firebrand, March 3, 1896, 2.
} 
applying them to what they saw as an overbearing American government. The fiery rhetoric of the era made great fodder for anarchist propaganda and the use of a quotation from a universally revered American figure to punctuate an argument would become a standard tactic of the American anarchists. Most issues of the Firebrand began with a poem, usually an original composition written for the paper by a contributor. On November 24, 1895, the newspaper opened with a poem titled "'Rah for 'Government"” a polemic on the evils of contemporary American government in which the author, after vociferously mocking current political trends, appropriates America's founding fathers in the final stanza:

Then Raise the red banner, The Flag without stain, The ensign of Washington, Franklin and Paine.

-Hail Columbia. ${ }^{166}$

The Firebranders frequently portrayed themselves as the inheritors of the American revolutionary tradition and references to the founding fathers were a common occurrence.

The anarchists' appropriation of America's revolutionary past was at its least subtle around the Fourth of July. The Firebranders attacked the patriotic displays of their fellow community members, denigrating the showy parades and the exuberant celebration of American soldiers while portraying their own revolutionary movement as the true embodiment of the spirit of 1776. Just before the Fourth of July in 1897, Addis lambasted the patriotism of his fellow Americans in a lengthy article in the Firebrand:

Immense military displays will be indulged in, and grand perorations of swelling words and high sounding phrases will be poured forth from the lips of stump-speakers and political orators. All to sound the praise of

166 “'Rah for "Government," Firebrand, November 24, 1895, 1. 
rebels and subverters of the social order. Does it not seem strange that such glory should be accorded to these men, when those who do the praising are so want to condemn the revolutionists of today? ${ }^{167}$

Addis explicitly compared his little group of anarchists, considered a small fringe group of undesirables by his fellow Portlanders, to America's most revered heroes. Boasts of this nature were commonplace in anarchist literature of the time as anarchists saw the great revolutions of the eighteenth and nineteenth centuries as the first steps on a path leading towards absolute freedom, with the great anarchist social revolution acting as the final part of this historical process. ${ }^{168}$

Following the American Revolution, many of the nation's founding heroes turned from bombastic revolutionary rhetoric to nation building. This included defining the very system of government that anarchists were so intent on overthrowing. The anarchists chose to ignore this aspect of their revolutionary heroes' careers. Instead they focused on those, like Jefferson and the anti-federalists, whose opposition to a strong centralized government could be easily appropriated by the late nineteenth century anarchists. Jeffersonian attitudes towards western expansionism played a central role in the anarchist formation of an ideal western society and Jefferson's anti-federalist writing proved to be just as popular with the anarchists as his work during the revolution. In one issue, the Firebranders published a quotation taken from a letter written by Thomas Jefferson in 1792 in which he declared that, "I am convinced that those societies, as the Indians, which live without government, enjoy in their general mass an infinitely greater amount

\footnotetext{
167 The Firebrand, Article "Fourth of July: The Spirit of '76" June 27, 1897, 1.

168 Unlike the followers of Marx, most anarchist communists did not believe in the materialist conception of history and did not see this process of transformation, from feudalism to absolute freedom, as a natural or inevitable process by something that required immediate human force to be created.
} 
of happiness than those who live under the European government." The Firebranders then used the quotation to argue that, "Jefferson, though a supporter of the 'free government,' was as thorough an example of the anarchist as history in his time affords." ${ }^{169}$ Jefferson, Paine, Franklin and even Washington were celebrated as libertarian heroes by the Firebranders for their actions during the Revolution, yet anarchists rarely contended with the actual complicated history and legacies of these figures. After all, many of the revolutionaries were slave owners, or participants in the establishment of a government that protected slave ownership. The anarchists preferred to ignore the aspects of the men's lives that contradicted their message.

While the anarchists occasionally condemned the bigotry of their intellectual opponents and refused to take part in the Sinophobia that was a defining feature of late nineteenth century Pacific Northwest radicalism, the newspaper rarely addressed the enormous levels of discrimination and violence that Black Americans faced in postReconstruction America. The anarchist's unwillingness to fully articulate a position regarding the realities of late nineteenth-century racism is surprising considering the way in which they had so brazenly thrown themselves into other social justice battles. The Firebrand publishers' unwillingness to engage with the realities of racial discrimination and violence reflected a preference towards the white working class and helps to explain why anarchism struggled to gain non-white supporters in the United States. Though the Firebranders ignored the horrors of contemporaneous racial violence and discrimination,

169 “A Hundred Years Ago," Firebrand, June 19, 1895, 4. 
they frequently alluded to the evils of slavery, often comparing the struggle against chattel slavery to their own struggle against economic exploitation:

Exchange of labor's products when for mutual advantage is co-operation, but commerce is one of the many varieties of slavery, with which we are afflicted. It has been custom to speak of chattel slavery only, as slavery and infer that all other forms of servitude were freedom; but the inference will not bear the weight of investigation. ${ }^{170}$

Instead of engaging with the true horrors of American slavery or examining its ongoing legacy, contributors to the newspaper instead chose to use slavery as a catchall comparison to the many modern evils against which the anarchists were struggling. For example, one Firebrand contributor compared the anarchist struggle against all forms of coercive authority to the struggle against the fugitive slave law, "as we long ago had to defy and set at nought the infamous Fugitive Slave Law, so it seems to me now even more imperative to repudiate all the laws, customs, traditions, and religions through which we get possession of wealth that other people and not themselves have created."171 The anarchists would never articulate a full throated attack against racism in the United States and instead focused their attention on the struggle to free white workers from an exploitative economic system.

The anarchists saw their own movement in opposition to hierarchical government as simply the next step in a long history of progress in the United States. Just as the colonists had challenged the authority of the British Empire, and as the abolitionists and union soldiers had stood against the institution of slavery, the American anarchists saw themselves as taking a similar stand against an oppressive and overbearing government

\footnotetext{
170 Viroqua Daniels, “A Few Pointers," Firebrand, February 17, 1895, 1-2.

${ }^{171}$ A.P. Brown "Then and Now." Firebrand, August 11, 1895, 4.
} 
and an exploitative economic system. While the Firebrand publishers and their contributors never fully addressed the subject of American racism they frequently debated the place that women's rights and free love should play within the larger anarchist struggle against the state.

\section{Women's Rights and Free Love - An American Anarchist Aberration}

While the Firebrand continued to publish articles concerning political and economic theory and remained engaged with larger global conversations regarding anarchist communist political philosophy, the newspaper also developed a unique national cultural identity based on its decision to print discussions of certain issues outside of traditional anarchist theory. The Firebrand's blasé discussion of sexuality, free love and women's rights reflected a growing intellectual divide between the culturally American anarchist communist movement and the anarchist movement in Europe. The publishers' decision to include these topics was a part of a unique American aberration of anarchist identity that drew inspiration from the much larger nineteenth century American libertarian tradition.

Free love and women's rights were a central focus of the Firebrand. For the Firebranders, free love and women's rights were inseparable from anarchism and the Portland anarchists therefore decided to nurture an ongoing discussion regarding these subjects. ${ }^{172}$ In the newspaper's first issue, in an article titled "The Cause of Sex Slavery,"

\footnotetext{
${ }^{172}$ An important influence on the Firebrand, particularly its discussions of women's rights and free love, was the newspaper Lucifer the Light-bearer, published by Moses Harmon in Valley Falls, Kansas and Chicago, Illinois from 1883-1907. In a letter to the Firebrand Moses described his paper thusly: "The Firebrand gives emphasis and prominence to economic and political subjects, but does not exclude social and sexologic reforms. Lucifer gives prominence and emphasis to social and sexologic questions, but does
} 
Chicago anarchist Lucy Parsons initiated an exchange with the newspaper's readers regarding what role the "sex question" should play in the anarchist movement. The exchange would last the entirety of the Firebrand's run and touch on issues of sex, women's rights and free love. Parsons argued that "the economic is the first issue to be settled; that it is woman's economical dependence which makes her enslavement possible" going on to ask the reader, "how many women do you think would submit to marriage slavery if it were not for wage slavery?"173 Parson's argument, that women's economic dependence on and "enslavement" to men was secondary and deeply connected to larger issues of economic inequality, reflected the ideas of leading European anarchist intellectuals, many of whom sought to delay discussions of marriage and women's rights until after the social revolution. Other anarchists, including most of the Firebrand publishers, saw the "sex question" as a crucial part of the social revolution and argued that an anti-authoritarian society could not be created without first establishing antiauthoritarian relations between the sexes.

The Firebrand's in-depth discussions of women's rights were in part a result of the central role that women played in the Firebrand and the larger American anarchist movement. While Mary Squires was its only female publisher, a majority of the newspaper's most well-known contributors were female. This included Lucy Parsons and Lizzie Holmes, who had been leading members of the English speaking American anarchist movement in Chicago before the Haymarket Riot, Californian poet and writer

not exclude governmental and economic subjects." Moses Harman, "A Greeting to The Firebrand," Firebrand, February 28, 1897, 7.

173 Lucy E. Parsons, "Cause of Sex Slavery," The Firebrand, January 27, 1895, 3. 
Viroqua Daniels, and Emma Goldman. As a result, the newspaper included many forthright discussions regarding the status of women in the United States. The Firebrand published several articles concerning the subject of oppressive female Victorian fashion, with many contributors arguing that they served no purpose but to "imprison women." In one article, the Firebranders noted that so many articles and correspondence had been sent to the newspaper regarding the subject that they would form an "Association for Emancipation from Foolish Customs" to oppose restrictive and impractical women's clothing: "Lots of women wear bloomers, divided skirts or breeches while riding a wheel, but oh, how few have the courage to wear them at any other time and yet they know how more convenient they are, but customs holds them as in a prison." ${ }^{174}$ Following the publication of the article announcing the tongue-in-cheek association, several women sent in their own accounts of their experiences wearing "bifurcated" garments, illustrating the way in which the newspaper had a large and energetic female readership that actively used the Firebrand's open platform structure, not just to advocate for anarchism, but to organize and fight for women's rights. While female contributors were actively involved in all aspects of the Firebrand, they drove the newspaper's ongoing conversations about women's rights and free love.

Free love and women's rights had become one of the most important elements of American anarchist ideology, but in Europe the subject would not receive the same level of interest. Upon meeting Mary Isaak, European anarchist communist philosopher Peter Kropotkin told her that Free Society, the Firebrand's successor, was "doing splendid

174 “Notes and Comments," Firebrand, September 12, 1897, 3. 
work" but then admonished her, stating that "it would do more if it would not waste so much space discussing sex." ${ }^{175}$ For Europeans, the sex question was not an essential part of the anarchist movement. As Kropotkin would tell Abraham Isaak, "I should advise you to leave alone the sexual question which the Firebrand devoted so much attention to. Free men and women will better find the ways for arranging their mutual relations than we can even foresee now. This is to be a result of the free work of an evolution of free life, in which any newspaper guidance is as illusory as it is in most cases wrong." ${ }^{176}$ Perhaps it was easy for the European anarchists to argue for patience when discussing women's rights because revolt, riot and terrorism had become the norm in Europe during the late nineteenth century. The Paris Commune of 1871 had made revolution seem inevitable to many European anarchists. Despite the volatility caused by the nation's rapid industrialization, the American Republic was as strong as it had ever been and there was no real indication of immediate collapse. American anarchists had to create the conditions of revolution and they believed that a major instigator would be equality in sexual relationships.

A uniquely American anarchist communist culture had developed on the pages of the Firebrand, in which anarchist communist theory was applied to the issues that mattered most to radical Americans. Women's rights, free love, and sexuality were now a center piece of the American anarchist communist platform. This unique perspective attracted new readers and enabled the newspaper to continue to grow and expand its operations. Unfortunately, the Firebranders' willingness to discuss taboo subjects like

\footnotetext{
175 Paul Avrich, "Kropotkin in America," International Review of Social History 25 No. 1 (April 1980), 18.

${ }^{176}$ Free Society, January 16, 1898. See also Avrich, "Kropotkin in America," 17.
} 
free love and sexuality would incense the local censors and give law enforcement an opportunity to bring an end to the controversial Portland newspaper. 


\section{Chapter IV - The Firebrand on Trial}

On January 10, 1897, roughly two years into publication, Addis once again assessed the position of the Firebrand, noting that, despite some setbacks, conditions in Portland were improving and the newspaper was more popular than ever, "We have not, perhaps, been called on to endure as much privation since the history of last year was written, as before, but that is due to slightly more favorable circumstances right around us." 177 The circumstances to which Addis referred were the growth of the Firebrand publishing group. Firebrand founder and professional printer J.H. Morris had rejoined the venture after returning from the Puget Sound area where he had been settling affairs following the death of his wife. Morris's skills in the print shop as well as his work at the editor's desk brought significant relief to the exhausted Addis and Isaak, even allowing them to take trips to the countryside to pick hops and blackberries to supplement their incomes. ${ }^{178}$ The second new arrival was Abner J. Pope, a seventy-seven year old greatgrandfather who had long been involved in radical activities. Despite his late arrival, Pope would quickly become an integral part of the Firebrand's operation, not only contributing to the labor of the newspaper but also providing much needed financial support, spending what remained of his fortune to support the newspaper and those involved. ${ }^{179}$ The anarchists were even able to move their base of operations to a small farm in Portland's Sellwood neighborhood. Pope seems to have come from wealth, but by the time he reached Portland he had by all accounts already exhausted most of his

\footnotetext{
177 Addis, “One Year's Experience" Firebrand, January 10, 1987, 2.

178 Ibid.

179 Pope claimed to have thirteen great grandchildren. "An Anarchist in Jail: A.J. Pope of the Vile 'Firebrand,' under arrest" Morning Oregonian, September 18, 1987, 10.
} 
fortune in support of several radical causes. What funds remained provided some stability to the newspaper and would allow him to later claim in an interview with the Morning Oregonian, that he was the paper's "principle stockholder." 180 In under a year Pope became so integral to the Firebrand's operations that he would be one of the three Firebranders, along with Henry Addis and Abraham Isaak, who would be arrested and convicted in 1897, and who would face, by far, the most serious consequences.

Surprisingly, it is from the pages of the Oregonian, not the Firebrand, that, the most complete description of the enigmatic A.J. Pope can be found. Even as the journalists of the business-minded Oregonian viciously attacked the Firebrand and its publishers, they could not help but be captivated and somewhat charmed by the old cantankerous anarchist, noting the unusual paradoxes that seemed to define the man, "as a descendent of the Pilgrim fathers, who does not consider himself a citizen of the United States, a Quaker who will not strike back, an anarchist who denies the right of any government to govern him and at the same time a believer in spiritualism, he is rather a singular being." ${ }^{" 181}$ This is an apt description of Pope. Out of a group of free-spirited anarchists, each with their own notable quirks, Pope was the quirkiest. Firstly, at the age of seventy-four, Pope was decades older than his companions. ${ }^{182}$ He had spent many years championing various radical causes and had a sense of recklessness not shared by the other publishers. He came from an old New England family and claimed he could

\footnotetext{
180 "An Anarchist in Jail," 10.

${ }^{181}$ Ibid.

182 Isaak was 33 at the time of his arrest while Isaak was 41 . Their birthyears were respectively 1864 and 1856. "Directory of Individuals," Emma Goldman A Documentary History of the American Years, 516 and 536.
} 
trace his ancestry to the Plymouth Colony. Pope came from a Quaker family and would frequently cite his Quaker heritage as the source of his rebellious nature and eventual conversion to anarchism. But, Pope was by no means born a pacifist. According to his interview with The Oregonian, "he had been so patriotic in his younger days that an effort had been made to get him appointed to West Point," revealing that his Quaker heritage and family were not a major influence until later in life. ${ }^{183}$ Once an adult, Pope became a pacifist. According to the Oregonian, it was this pacifism that led to Pope's complete rejection of representative democracy because he had decided that "if he had voted for a man and this man had voted to send troops into the South to kill people, he would have considered himself a murderer." ${ }^{184}$ Pope credited his American heritage, his New England upbringing, and his Quaker faith as the primary factors that informed his pacifist and anarchist identity, and while this may have seemed peculiar to the Oregonian and its readership, it made perfect sense to the Firebrand's audience, many of whom had come to anarchism through their own American identity.

Pope had become so central to the newspaper that when the Isaak family and Henry Addis travelled south to Marion County on one of their hop picking trips in the Fall of 1897, Pope stayed behind in Sellwood to oversee the management of the newspaper. The group had increased their workload during the previous weeks to make sure they had a few issues pre-printed but they still needed someone to stay behind and ensure that the papers were delivered on time to the local post-office. It was in this capacity that Pope headed to the Sellwood post office on September 17, 1897. Pope had

\footnotetext{
183 "An Anarchist in Jail," 10.

${ }^{184}$ Ibid.
} 
just successfully dropped off the most recent issue of the Firebrand when the elderly anarchist was approached by a stranger who insinuated that he was also an anarchist and engaged Pope in conversation. The man was in fact United States Deputy Marshall Humphrey, who was part of a sting operation to arrest the Firebrand publishers. The deputy used the conversation to ascertain intimate details about the newspaper and its principle publishers, learning that both Addis and Isaak were in Marion County. Pope also claimed to be the principle stockholder of the newspaper.

Pope headed home, likely unaware that a local postal inspector was at that moment combing through the recently delivered newspapers. The inspector found that the issue "contained a lot of matter which he considered indecent and obscene, at once made complaint to United States Attorney Murphey, and a warrant was issued for the arrest of Pope." 185 At roughly 1:30 PM Pope was brought to the United States' Attorney's office where he was told that "he ought to know better than to mail such papers, and lay himself liable to imprisonment in the penitentiary." Pope reportedly replied that "men differed in regard to what was proper what is right, and what is nice" and that "if the government would not allow his papers to be mailed that settled it. He would take them home again." ${ }^{186}$ Pope was of course not allowed to leave and was instead taken before the United States' Commissioner where bail was set at $\$ 2,000$, an exorbitant amount of money well out of reach for the impoverished anarchist. When informed that he would therefore be taken to jail, he replied, "You have the power, and can put me in jail if you

185 “An Anarchist in Jail," 10.

186 Ibid. 
like." 187 This statement reflected Pope's Thoreau-inspired personal philosophy of civil disobedience that would define his actions throughout the subsequent trial. Pope intended to act as a martyr and refused to take any actions that compromised his anti-statist principles.

The Firebranders would later learn that postal inspectors had been keeping an eye on the Firebrand for some time. According to the Oregonian, authorities received complaints about the newspaper from individuals across the country. ${ }^{188}$ Supporters of the Firebrand had assumed the newspaper was targeted by the censors because of its frank discussions of anarchism and revolution. After all, anarchist terrorism was one of the defining features of the 1880 s and 1890 s. ${ }^{189}$ The image of the anarchist bomb thrower had been seared into the minds of Americans, and even though the Firebranders never participated in any violent actions themselves the term anarchism had become synonymous with terror. As one contributor to the Firebrand put it, "When I was at school, I used to think that Anarchists were men with fierce eyes, who wore large hats and long cloaks each carrying a dagger and a bomb and when you looked at them you could read the word 'Murder' on their faces." ${ }^{\prime 90}$ While it was only a minority of anarchists who advocated for violence and an even smaller minority that actually practiced violence, there was a global crackdown on anarchism. ${ }^{191}$ Despite the extreme

\footnotetext{
187 “An Anarchist in Jail," 10.

188 "Publishers of the Firebrand on Trial," The Evening Telegraph, January 3, 1898.

${ }^{189}$ A short list of anarchist violence during the 1890s includes, Berkman's attempted assassination of Henry Clay Frick in 1892, a string of Café bombings in Paris, the Assassination of French President Sadi carnot, the Assassination of the Spanish Prime Minister Antonio Canocas del Castilo and the assignation of Empress Elisabeth the consort of Emperor Franz Joseph I of Austria Hungary.

190 "Anarchist Girls Group," The Firebrand, April 25, 1897, 7.

${ }^{191}$ For an account of the philosophical origins of anarchist terrorism see Joll, The Anarchists, 99-129. For an in-depth account of the history of anarchist terrorism and the international movement to suppress it
} 
anti-anarchist sentiment that characterized the period, the articles targeted for prosecution by the authorities in the Firebrand case had little to do with anarchism, violence, or revolution. Instead they were targeted because of their overt discussions of sex and free love under the Comstock Act which disallowed the use of the U.S. Postal Service for the sending of obscene materials.

The prosecution targeted three specific Firebrand articles during the trial. The first piece was a reprinting of Walt Whitman's sexually explicit poem “A Women Waits for Me." The two other offending articles dealt with the subject of free love and were responses written by two readers to an article that had been published in the Firebrand in an earlier issue. In the original article, which was not targeted by the censors, the author, Mrs. B., argued that until men and society in general were better educated, free love relationships would be just as oppressive for women as traditional marriage. To support this argument Mrs. B. provided an autobiographical account of her own relationship with the father of her children, which, despite being a free love relationship, resulted in her abandonment to a life as a single mother while her partner carried on with other women. Mrs. B. blamed economic conditions and her former partner's upbringing as the cause of her misery and argued that certain societal changes must be implemented before free love could truly liberate American women. ${ }^{192}$ The second article targeted by the censors, was a response to Mrs. B.'s argument, in which the author placed the blame on both Mrs. B. and the father of her children arguing that most men and women were "respectable"

see John M. Merriman, The Dynamite Clube: How a Bombing in Fin-de-Siècle Paris Ignited the Age of Modern Terror (New Haven: Yale University Press, 2009).

192 Mrs. B., "Open Letter to E.F. Ruedebusch," Firebrand, March 28, 1897, 7. 
enough not to abandon their children. ${ }^{193}$ The third article was an in-depth response to Mrs. B's original letter, in which the author agrees with Mrs. B's argument that women would remain oppressed even in free love relationships. The author, likely Tacoma's Al Klemencic, argued that "sexual freedom, in the present stage of its development, means greater slavery for the average woman who embraces it," and that "the masculine gender is not yet sufficiently advanced in the practical application of the opinions which he holds to realize this fact, or rise above the condition of master he has so long held."194 To illustrate this point, the author presented a hypothetical situation in which two couples and one single man spent the night together and "exchanged partners." While the author did not argue that free love equated to this kind of activity, he used the hypothetical situation to illustrate the way in which men could abuse women in a free love relationship just as they could in a traditional relationship, by coercing the women into sex. Compared to other articles that had been published in the Firebrand, the targeted pieces were relatively tame. But taken out of context, these articles were the perfect basis for a sensationalized obscenity trial, in which frank discussions of sex were not just considered lewd but illegal.

On January 2, 1898, the Firebranders finally had their day in court. Proceedings began at ten in the morning in Portland's U.S. District Courthouse with Judge Charles B. Bellinger presiding over the case. The trial got off to a quick start following the Firebranders' attorney's questionable decision to refuse his right to question jury candidates during the jury selection process. The Firebranders had secured a court

\footnotetext{
193 Kate Austin, “A Woman's View of It," Firebrand, August 25, 1897, 6-7.

194 A.E.K., "It Depends on the Woman," Firebrand, August 25, 1897, 7. 
appointed lawyer by the name of Henry McGinn, who seemed wholly focused on getting the case dismissed based on the argument that the tactics used by law enforcement to acquire physical copies of the Firebrand and to arrests its publisher amounted to entrapment. In his opening statement, McGinn argued that the postal inspectors had resorted to the use of a decoy letter "to entrap the defendants into the commission of a crime. ${ }^{" 195}$ United States District Attorney John H. Hall, representing the prosecution, utilized his opening statement to attack the moral content of the Firebrand newspaper, arguing that articles in the newspaper were "lascivious rude and lewd and not fit even for adults to read." ${ }^{\prime 196}$ Attacks on the moral content of the Firebrand would be the primary tactic used by the prosecution throughout the case. The prosecution called several witnesses to the stand to establish that the defendants were in fact the publishers of the Firebrand and had been sending the newspaper through the mail for some time. Some of the witnesses called by the prosecution included J.W. Campbell, the Firebranders' Sellwood landlord who confirmed he had rented the premises in which the newspaper was published to the defendants, and Charles Doring, an acquaintance of the Firebranders who attested to purchasing the newspaper from the group of men since the release of its first issue. W.W, Sproul, the librarian at the People's Free Library, the very institution that Addis had helped establish some six years earlier, testified that the library had been receiving the newspaper for some time but that he did not know who had been delivering the papers to the library. The librarian claimed that all he knew was that they arrived in the library's paper box along with the other newspapers. The prosecution also called

195 "Publishers of the Firebrand on Trial," Evening Telegraph, January 3, 1898, 6;

196 Ibid. 
several postal employees, who had regularly processed and mailed out the Firebrand. The prosecution then read aloud from the targeted articles and introduced them as evidence. Surprisingly, McGinn made no objections, even though this action was clearly determinantal to his case. The final witness to take the stand for the prosecution was W.A. Robinson, the postal inspector who had spearheaded the case against the Firebrand and who had acquired the newspaper using the invented name R.A. Williams. For the first time, McGinn took the opportunity to cross examine one of the government's witnesses, and engaged in a tense back-and-forth with the inspector, questioning the way in which he conducted his investigation. In one heated exchange, McGinn asked the inspector if he warned the Firebranders that they were mailing illicit materials, to which Robinson argued that this was not his business. "Your business is to entrap people?" responded the impassioned attorney. Following this exchange, McGinn asked that the judge dismiss the case as the postal inspector had broken protocol by using a fake name and fake address to secure copies of the Firebrand. The motion was over-ruled, and the defenses' entire strategy had been defeated before McGinn even had the opportunity to call a single witness. ${ }^{197}$

The first witness called by the defense was Addis, who admitted that he had been a part of the Firebrand publishing group but denied publishing or mailing the issue that had been targeted by the postal inspectors. The defense then called Pope to the stand, who, true to his anarchist principles, refused to take the oath and then upset the

197 "Publishers of the Firebrand on Trial," 6; "Misused the Mails: Pope, Addis and Isaacs are Convicted," Morning Oregonian, January 4, 1898, 8. 
courtroom by launching into a tirade about the evils of government. ${ }^{198}$ Judge Bellinger interceded and brought Pope's outburst to a premature end. The defense did not call any further witnesses, Isaak was not called to the stand, and the court proceeded to closing arguments. In their final arguments, the prosecution once again lectured the jury about morality and again described the paper's blatant discussions of sex and free love, while McGinn, by all accounts, made a halfhearted defense of the right to freedom of speech. McGinn had based his entire defense on the issue of entrapment, hoping to get the case dismissed and when the argument was denied by the judge, the defense quickly fell apart. With that, the judge dispatched the jury, who, after only a half hour of deliberation, returned with a guilty verdict. Addis and Isaak were released on bail, and, on Judge Bellinger's recommendation, told the press that they planned to appeal for a retrial. Pope, on the other hand, refused to take part in the retrial and accepted his sentence of four months in jail and a dollar fine.

Before the second trial could take place, the case against Addis and Isaak was dismissed by United States District Attorney John Hall in exchange for the two anarchists" promise that they would discontinue publication and "burn all copies of the sheet." 199 The men initially did as they were told and shuttered the Firebrand. Using the money that had been collected for the Firebrand defense fund, Addis and Isaak moved to San Francisco, where they defiantly resumed publication, this time under the name Free Society. Meanwhile, Pope remained in prison.

\footnotetext{
198 "Conviction of the Firebrand Trio," Evening Telegraph, January 4, 1898, 6.

199 “An Anarchist Was Here," Morning Oregonian, September 10, 1901, 12. 
Some have argued that Pope's refusal to pursue a retrial had less to do with his convictions and more to do with his desire to spend the rest of winter in a heated cell. As historian Carlos Schwantes put it, "The stubbornness of the elderly Pope was no doubt subtly reinforced by the stark contrast between the rigors of trying to survive a cool, damp Oregon winter on canned blackberries and the comparative luxury of three square meals a day in the clean steam-heated county jail." ${ }^{" 200}$ This reasoning seems likely considering the fact that Pope was homeless for several weeks following his release from prison. After the trial, the elderly anarchist continued to play up his prison story, posting the following notice in a recently established anarchist communist newspaper, Discontent: The Mother of Progress: "Comrade A.J. Pope will send his photo, with an account of the Firebrand case on back to anyone who will send him 4 cents and any other amount to aid him and the cause for which he was persecuted." ${ }^{201}$ While Addis and Isaak took the defense fund and moved to California, the elderly Pope would come to depend on charitable support.

As soon as it had been announced that Pope, Addis, and Isaak had been arrested, the American anarchist community quickly mobilized to support the incarcerated publishers. In Chicago, a rally was held to raise money for the incarcerated Firebranders. Emma Goldman, Lucy Parsons, and Moses Harman, the editor of Lucifer the Lightbearer, all made speeches on behalf of the incarcerated radicals, but, according historian Carlos Schwantes, the rally's fundraising efforts were undercut by Parsons who

\footnotetext{
${ }^{200}$ Schwantes, Free Love and Free Speech on the Pacific Northwest Frontier, 288.

201 Discontent: The Mother of Progress, July 13, 1898, 4.
} 
admonished the Firebranders for their inclusion of "dirty" subject matter. ${ }^{202}$ In New York City, the city's Jewish anarchist community proved to be much more successful in their fundraising efforts, netting fifty dollars for the defense fund at their Yom Kippur meeting. ${ }^{203}$ Radicals from across the country sent letters to the District Attorney in support of the three incarcerated anarchists. According to the Oregonian, which openly mocked the American anarchists' response to the arrest of the Firebrand publishers, "anarchists from all parts of the country are sending in protests against the prosecution against Pope, Addis, and Isaacs, of the obscene Firebrand." The Oregonian referred to these anarchists as "go-as-you-please creatures" who did not understand the truth of the first amendment, that "the founders of our Republic, while they declined to erect a state church or define a state religion, did undertake to found a state upon the fundamental principles of modern government." ${ }^{204}$ The Oregonian responded to the anarchists and all supporters of unlimited free speech with condescension, continuing the newspaper's long standing opposition to local radicalism. ${ }^{205}$ The American anarchist movement's lively reaction to the arrest of the Firebranders reflects just how influential the Firebrand had become.

In just two years and eight months, the newspaper had grown from a backwoods journal, published by a group of unknown radicals, into the most important English

\footnotetext{
202 Schwantes, Free Love and Free Speech on the Pacific Northwest Frontier, 285.

203 Ibid.

204 “Crime Called Religion," Morning Oregonian, September 21, 1897, 4.

205 The editors of the Oregonian published a pro-Firebrand letter that had been sent to the district attorney by Charles L. Penhallow a Massachusetts anarchist who would later publish the anarchist Discontent: The Mother of Progress. Penhallow defended Pope, stating, "I beg that you will use your best efforts in behalf of Abner Pope. I know him to be a noble, honest tender-hearted man. Teaching a higher code of moral and social life is not obscenity." See, "Aid for an Anarchist: Letter from a Sympathetic Friend to the United States Attorney," Morning Oregonian, October 6, 1897, 6.
} 
language anarchist communist newspaper in the United States. While the paper ended abruptly, its legacy would live on, as the Americanized anarchist movement it had established became the dominant strain of anarchism in the United States and influenced radical American culture for the next two decades. 


\section{Conclusion: The Firebrand's Legacy}

Though the obscenity trial meant the end of the Firebrand, the movement it had created would live on. Pope, Isaak, and Addis, as well as many of the Firebrand's prominent readers and contributors, would form the foundations of a growing national anarchist intellectual community that, though small in size, would be profoundly significant over the next two decades. In the twenty-year period that followed the collapse of the Firebrand, the American anarchist movement was dominated by culturally American figures and newspapers. During this period, the Americanized anarchist movement had two intellectual centers, both of which had direct ties to the Firebrand. The first intellectual community was centered around Abraham Isaak's Free Society, a culturally American anarchist communist newspaper published from 1898 to 1904. The second was the anarchist utopian community of Home, Washington where a series of English language anarchist newspapers would be published from 1898 to 1912 . Both communities would carry on the work of the Firebrand by providing forums in which American radicals could continue to create community and debate anarchism.

Free Society was founded in San Francisco by Isaak and Addis in the months following the Firebrand trial. The newspaper was intended to be a continuation of the Firebrand, but Addis returned to Portland soon after Free Society's foundation, and the newspaper would then take on a life of its own. Free Society was Isaak's paper, he was its sole editor and the Isaak family was its printers. Under the direction of Isaak, Free Society became a more cohesive and professional newspaper than its predecessor, lacking the rough-spun quality, scattered focus, and copious spelling mistakes that had defined the Firebrand. While the Firebrand's amateurism endeared the newspaper to an audience 
of like-minded, marginalized radicals, the professionalism of Free Society attracted the attention of anarchism's greatest minds, drawing original contributions from such figures as Leo Tolstoy, Peter Kropotkin, Elisee Reclus, and Errico Maletesta. ${ }^{206}$ When Free Society relocated to Chicago in 1901, it moved from the periphery to the very heart of the American anarchist movement. The newspaper quickly became a central fixture in Chicago's radical community and the Isaaks befriended some of the nation's most wellknown radical figures, such as Hull House founder Jane Addams and leading civil rights attorney Clarence Darrow. ${ }^{207}$ The Free Society family included some of the best-known anarchists in the United States. Emma Goldman, Voltarine De Cleyre, and Hippolyte Havel, were all members of this new culturally American intellectual community.

Despite the newspaper's many accomplishments, Free Society is largely remembered for its connection to Czolgosz and the assassination of President McKinley. The Isaaks, Emma Goldman, and a few other associated anarchists were arrested following the assassination. Though Czolgosz claimed to have acted alone he cited both the speeches of Emma Goldman and articles published in Free Society as his inspiration. Czolgosz had even met with Isaak and Goldman in Chicago two months before the assassination. Both Isaak and Goldman had found the young man to be somewhat unpleasant, with Isaak even suspecting him of being a government spy. ${ }^{208}$ None of the

\footnotetext{
206 Reichhert, Partisans of Freedom, 267.

207 When members of the Isaak family were arrested in connection with the McKinley assassination, Jane Addams sent a letter to Clarence Darrow requesting that he act as their attorney. The Isaak's were released soon thereafter without any charges and therefore nothing came of Addam's efforts. Clarence S. Darrows, "Clarence Darrow to Jane Addams, September 11, 1901," Jane Addams Digital Edition, accessed February 14, 2018, https://digital.janeaddams.ramapo.edu/items/show/894.

208 Miller, The President and the Assassin, 285-288.
} 
Chicago anarchists were charged in connection with the assassination and all were eventually released. After the incarceration of the Free Society group the newspaper continued for a few more years before printing its last issue in $1904 .{ }^{209}$ For nearly seven years Free Society had been the principle English language anarchist newspaper in the United States. ${ }^{210}$ Emma Goldman would carry on the Free Society cause in her own newspaper, Mother Earth, which she published from 1906 to 1917. According to historian Peter Glassgold, the newspaper was in part, "Goldman's attempt to fill the literary gap with the 1904 closing of Isaak's journal, Free Society."211 During World War I, Goldman used the publication to place the culturally American anarchist movement at the very heart of the anti-war effort. Police targeted anarchist agitators vigorously during and after the war and the culturally American anarchist movement never fully recovered. Many of its members were deported, including Emma Goldman, while others simply disassociated from the movement to avoid prosecution. ${ }^{212}$

The second center of America anarchist activity was Home, Washington, an anarchist utopian community located on Puget Sound, southeast of Tacoma. The origins of the community can be traced to the pages of the Firebrand, where members of the socialist utopian community of Glennis Colony, in a letter to the newspaper, told the

\footnotetext{
${ }^{209}$ The Isaaks would later return to California where they would form the Aurora Colony, an anarchist inspired utopian community. By 1920, the colony had disbanded but Abe and Mary Isaak would remain at the site of the former colony, on the farm they had built together for the rest of their lives. Mary died in 1934 and Abraham died in 1937. Smith, "Further Notes on Abraham Isaak," 89-93.

210 "Free Society was the principle English-language forum for anarchist ideas in the United States at the beginning of the twentieth century." "Directory of Individuals," in Emma Goldman a Documentary History of the American Years: Volume One Made for America, 1890-1901, ed. Candace Falk (Berkeley: University of California Press, 2003), 564.

${ }^{211}$ Smith, "Further Notes on Abraham Isaak," 83.

${ }^{212}$ Reichert, Partisans of Freedom, 441-442.
} 
readers that the Firebrand newspaper had convinced them of the rightness of anarchism. During one of his propaganda tours in Washington, Addis reported back to the Firebrand that "The Glennis Co-operative Colony has, through his [Fireband supporter Al Klemencic's] interest in its welfare, and his exposition of anarchist principles, become much nearer an anarchist settlement than a nationalist colony, as originally designed." 213 These men ultimately abandoned Glennis Colony and established a new colony near Lakebay, Washington that was to be based on anarchist principles. The new community was called Home, and Oliver Verity, one of its three founders, wrote a letter to the Firebrand just after the community's establishment. ${ }^{214}$ Verity wrote:

Comrade Addis has thoroughly outlined, in a recent number of the Firebrand, the principles that we have here put in practice; i.e., perfect freedom for individuals to work and adopt any system they may choose, either collectively or singly. . . To any one interested in obtaining a home where better conditions prevail, I would say we are making success of it here and invite all to join us. ${ }^{215}$

This letter illustrates the foundational role the Firebrand played in shaping the anarchist principles of the Home Colony. The Firebrand was also responsible for the development of the Tacoma area anarchist community from which Home would draw much of its support and membership. One of the Firebrand's most engaged non-Portland contributors was Tacoma's Al Klemencic, who through active organization efforts and the distribution of the Firebrand, was able to develop a strong anarchist movement in the city, something the Firebranders had failed to do in their own community. When Henry

\footnotetext{
213 Addis, "The Work of Propaganda," 3.

214 A. Klemencic, "The Glennis Co-Operative Industrial Colony," Firebrand, March 31,1895; 2. Addis, "Work of Propaganda," Firebrand, June 2, 1895, 3; A.O. Verity, "Theory and Practice," Firebrand, June 21, $1896,2$.

215 Oliver Verity, "Theory and Practice," Firebrand, June 21, 1896, 2.
} 
Addis went on a propaganda tour through Washington, he was shocked to discover that the Firebrand and the American anarchist communism it promoted had developed such a strong following: "All in all, anarchism has a footing that I had not found elsewhere. It is permeating every strata of society." ${ }^{216}$ Addis may have indeed been exaggerating, but the establishment of Home and the support it would receive from neighboring Tacoma supports his assertion that western Washington was becoming a bastion of anarchism.

Like good anarchists, one of the Home Colony settlers' first actions was to establish a press and release a newspaper, the short-lived New Era. ${ }^{217}$ The newspaper quickly folded but was succeeded by a series of successful anarchist newspapers, each with a different thematic focus that reflected different intellectual developments within the movement. The second newspaper published at Home was Discontent: The Mother of Progress, which was in many ways a continuation of the Firebrand, adopting its open platform model, its anarchist communist perspective, and an exaggerated version of its culturally American perspective. ${ }^{218}$ After leaving San Francisco, Addis spent some time at Home Colony and became a significant contributor to Discontent. Later, after he had returned to Portland, Addis created problems for the newspaper when his articles on free love attracted the attention of the local censors. Though the Home colonists held up better in court than the Firebranders, Discontent would collapse soon thereafter. ${ }^{219}$

\footnotetext{
216 "Henry Addis, “Anarchy in Washington," Firebrand, November 24, 3.

${ }^{217}$ For a good overview of the History of Home, Washington see, Justin Wadland, Trying Home: The Rise and Fall of an Anarchist Utopia on Puget Sound (Corvallis: Oregon State University Press, 2014) and Charles Pierce LeWarne, Utopias on Puget Sound, 1885-1915 (Seattle: University of Washington Press, 1975).

${ }^{218}$ For example, in one issue of Discontent, on a single page, the publishers included quotations from Jefferson, Emmerson, Wendel Phillips, and William Shakespeare, each bolded and separated from the pages' larger articles, Discontent, July 20, 1898, 3.

219 LeWarne, Utopias on Puget Sound, 175; Wadland, Trying Home, 46-48.
} 
Subsequent Home Colony newspapers reflected changes in the rapidly developing American anarchist movement. The colony's third newspaper, The Demonstrator, made freedom of speech its central cause. This was in response to the anti-obscenity trial that had shuttered its predecessors. ${ }^{220}$ The Demonstrator also supported the newly established Industrial Workers of the World, (IWW), even publishing an ongoing column that focused on the development of the "One Big Union" and the larger American syndicalist movement. Home colony's final newspaper, The Agitator, edited by long time anarchist activist Jay Fox, was an outright anarcho-syndicalism newspaper that merged the antiauthoritarian political philosophy of the anarchist movement with the labor based direct action tactics of revolutionary industrial unionism. Over time, The Agitator focused more heavily on syndicalism. In 1913, Fox moved the newspaper to Chicago, where it became the mouthpiece of the Syndicalist League of North America, changed its name to The Syndicalist, and largely disassociated from the anarchist movement. ${ }^{221}$

The shifting thematic focuses of the Home Colony newspapers reflected larger transformations within the American anarchist movement and illustrates the way in which the culturally American anarchist movement played a central role in the development of the American free speech and syndicalist movements. Anarchists continued to be on the front lines in the battle against Comstockism, as their publications and speeches continued to draw the ire of the censors. ${ }^{222}$ The anarchists were also some

\footnotetext{
220 James F. Morton, "Freedom of Expression," Demonstrator, March 11, 1903, 1.

${ }^{221}$ LeWarne, Utopias on Puget Sound, 208-210.

222 Brigette Koenig, "Law and Disorder at Home: Free Love, Free Speech, and the Search for an Anarchist Utopia," Labor History 45, no.2 (2004): 199-223. See also, Schwantes, "Free Love and Free Speech on the Pacific Frontier,"273.
} 
of the earliest supporters of the syndicalist movement and the Industrial Workers of the World. The role that anarchists and anarchism played in the foundation and development of the IWW has not received the scholarly attention that the subject deserves. While many historians have abjectly denied the anarchist's influence on the IWW, there are obvious connections. Firstly, there is considerable overlap between the IWW and the anarchist communists in terms of their core beliefs. Both movements shared a strong belief in the efficacy of direct action tactics, the need for immediate revolutionary struggle, and a deep-seated faith in the revolutionary potential of society's most marginalized citizens. ${ }^{223}$ It should also be noted that members of the culturally American anarchist movement, including some of the Firebrand's most significant supporters, attended the IWW's founding convention. Lucy Parsons, Al Klemencic, and Jay Fox were all in attendance. ${ }^{224}$

Most importantly, anarchism would come to be the radical vanguard of the American left during the progressive era. Though only a small minority of Americans would self-identify as anarchists, as the term continued to develop an increasingly negative connotation due to its connection to terrorism, countless radicals would be inspired by its uncompromising tenants. After all, whenever Emma Goldman came to Portland, she would attract large crowds of sympathetic radicals and curious onlookers, and while very few of these people self-identified as anarchists, many radicals were

\footnotetext{
${ }^{223}$ For further information of the culturally American anarchist movement's influence on the IWW, see Salverto Salerno, Red November Black November: Culture and Community in the Industrial Workers of the World (Albany: State University of New York, 1989).

${ }^{224}$ Salerno, Red November Black November, 69-90.
} 
inspired by her powerful speeches. ${ }^{225}$ The American anarchist movement played an important role in shaping the ideas of radicals across the country by bringing an extreme libertarian perspective to the forefront of the nation's consciousness.

The role that the Firebrand played in the development of this American anarchist movement should not be understated. A small group of unknown Portland radicals completely altered the landscape of anarchism in the United States. The newspaper's unique perspective was shaped by the publisher's experiences in Gilded Age Portland and reflected the struggle of the country's most marginalized citizens: the itinerant worker, the tramp, and the unskilled worker, all of whom struggled to find representation within Portland's more traditional radical organizations. The newspaper's open platform format, along with its culturally American perspective, attracted a new generation of anarchists to the cause who would participate in radical counterculture well into the next century. The Firebrand therefore deserves a more prominent place in the history of American radicalism.

${ }^{225}$ For a description of Goldman's visits to Portland during the early twentieth century and their impact on the local radical movement, see Michael Helquist, Marie Equi: Radical Politics and Outlaw Passions (Corvallis: Oregon State University Press, 2015), 134-136. 


\section{Bibliography}

\section{Newspapers}

The Agitator. Home, WA, 1910-1912.

Chicago Tribune. Chicago, IL,1847-.

The Dalles Chronicle. The Dalles, OR, 1890-

Daily Capital Journal. Salem, OR, 1903-191.

The Demonstrator. Home, WA, 1903-1908.

Discontent: The Mother of Progress. Home, WA, 1898-1902.

Evening Telegraph. Portland, OR, 1877-1931.

Free Society. San Francisco, CA, Chicago, IL, New York, NY, 1897-1904.

The Firebrand. Portland, OR, 1895-1897

Hillsboro Independent. Hillsboro, OR, -1932.

Lucifer, the Light-Bearer. Valley Falls, KS, Topeka, KS, and Chicago, IL, 1883-1907.

Oregon City Enterprise. Oregon City, OR, 1891-1922.

Oregonian. Portland, OR, 1850-.

New York Times. New York, NY, 1851-.

The Rebel. Boston, MA, 1895-1896.

Solidarity. New York, NY, 1892-1898.

\section{Archival Sources}

Abigail Scott Duniway Papers, Mss 432, Oregon Historical Society Research Library, Portland, Oregon.

Jay Fox Papers, 1909-1970, University of Washington Suzzallo and Allen Libraries, Seattle, Washington.

\section{Correspondence}

Darrows, Clarence S. "Clarence Darrow to Jane Addams, September 11, 1901." Jane Addams Digital Edition. Accessed February 14, 2018. https://digital.janeaddams.ramapo.edu/items/show/894.

\section{Interviews}

Isaak, Elmer B. "Elmer B. Isaak.” Interview with Paul Avrich, New York City, February 12, 1974 in Anarchist Voices: An Oral History of Anarchism in America ed. Paul Avrich. Oakland: AK Press, 2005, 27-28.

Urmath, Grace. "Grace Urmath." Interview with Paul Avrich, Anarchist Voices: An Oral History of Anarchism in America. ed. Paul Avrich. Oakland, AK Press, 2005, 23-26. 


\section{Encyclopedia Articles}

Lipin, Lawrence. "Populism in Oregon." The Oregon Encyclopedia. https://oregonencyclopedia.org/articles/populism_in_oregon/\#.WUyd42jyvIU.

Robbins, William G. "Oregon Donation Land Act." Oregon Encyclopedia. https://oregonencyclopedia.org/articles/oregon_donation_land_act/\#.WoawHKinHI $U$.

\section{Books and Journal Articles}

Abbott, Carl. Portland in Three Centuries: The Place and the People. Corvallis: Oregon State University Press, 2011.

Avrich, Paul. An American Anarchist: The Life of Voltarine de Cleyre. Princeton, Princeton University Press, 1978.

—. Anarchist Portraits. Princeton: Princeton University Press, 1988.

—. The Haymarket Tragedy. Princeton: Princeton University Press, 1984.

Bantman, Constance and Altena, Burt eds. Reassessing the Transnational Turn: Scales of Analysis in Anarchist and Syndicalist Studies. Oakland: PM Press, 2017.

Balleck, Barry J. "When the Ends Justify Means: Thomas Jefferson and the Louisiana Purchase," Presidential Studies Quarterly 22, no. 4 (Fall 1992): 679-696.

Blatt, Martin Henry. Free Love and Anarchism: The Biography of Ezra Heywood. Urbana: University of Illinois Press, 1989.

Brown, James Patrick. Anarchy and Individualism in American Literature: From Walden Pond to the Rise of the New Left. University of Minnesota, 2013.

Buhle, Paul. "Anarchism and American Labor." International Labor and Working-Class History 23 (Spring 1983): 21-34.

Carr, E.H., Michael Bakunin. 1937; reprint, New York: Vintage Books, 1961.

Clanton, Gene. Populism, the Humane Preference in America, 1890- 1900. Boston: Twayne Publishers, 1991. 
Boyer, William Haas. Oregon Politics and the Evolution of the Populist Movement In Portland, 1880-1898 (Dissertation). Eugene, Oregon: University of Oregon, 2003.

Eisenberg, Ellen. Embracing a Western Identity: Jewish Oregonians 1840-1950. Corvallis: Oregon State University Press, 2015.

Falk, Candace, Ed. Emma Goldman: A Documentary History of the American Years, Volume One. Berkeley: University of California Press, 2003.

Ferguson, Kathy E. "Anarchist Printers and Presses: Material Circuits of Politics." Political Theory 42, no. 4 (May 14, 2014): 391-414.

Goldman, Emma. Living My Life: Volume 1. New York: Dover Publications, 2012.

Goodwyn, Lawrence. Democratic Promise: The Populist Moment in America. Oxford: Oxford University Press, 1976.

Greenwood, Laura. The Anarchist Periodical Press in the United States: An Intertextual Study of Prison Blossoms, Free Society, and The Demonstrator [Dissertation]. Peterborough, Ontario, Canada: Trent University, 2016.

Helquist, Michael. Marie Equi. Radical Politics and Outlaw Passions. Corvallis: Oregon State University Press, 2015.

Hummasti, Paul George. "Finnish Radicals in Astoria, Oregon, 1904-1940: A Study in Immigrant Socialism." PhD diss., University of Oregon, 1975.

Johnson, Jeffrey A. "They are All Red Out Here": Socialist Politics in the Pacific Northwest, 1895-1925. Norman: University of Oklahoma Press, 2008.

Johnson, Robert D. The Radical Middle Class: Populist Democracy and Question of Capitalism in Progressive Era Portland, Oregon. Princeton, Princeton University Press, 2003.

Joll, James. The Anarchists. Cambridge: Harvard University Press, 1980.

Koenig, Brigitte Anne. American Anarchism: The Politics of Gender, Culture, and Community from Haymarket to the First World War [Dissertation]. University of California, Berkely, 2000.

Kraut, Julia Rose. "Global Anti-Anarchism: The Origins of Ideological Deportation and the Suppression of Expression." Journal of Global Legal Studies 19, no. 1 (Winter 2012): 169-93. 
Lansing, Jewel Beck. Portland: People. Politics, and Power, 1851-2001. Corvallis, Oregon State University Press, 2003.

LeWarne, Charles Pierce. Utopias on Puget Sound, 1885-1915. Seattle: University of Washington Press, 1975.

—. "The Anarchist Colony at Home, Washington, 1901-1902." Arizona and the West 14, no. 2 (1972): 155-68.

Longa, Ernesto A. Anarchist Periodicals in English Published in the United States (18331955): An Annotated Guide. Scarecrow Press, 2009.

Lumsden, Linda J. Black, White, and Red All Over. Kent: The Kent State University Press, 2014.

MacColl, Kimbark and Stein, Harry H. Merchants, Money and Power: The Portland Establishment 1843-1913. Portland, Oregon: The Georgian Press, 1988.

Martin, James J. Men Against the State: The Expositors of Individualist Anarchism in America, 1827-1908. Colorado Springs: Ralph Myles Publisher, 1970.

McClean, George N. The Rise and Fall of Anarchy in America. New York: Haskell House Publishers, 1972.

McElroy, Wendy. "Culture of Individualist Anarchism in Late 19th Century America." Journal of Libertarian Studies 5, no. 3 (1981): 291-304.

McMath, Robert C. Jr. American Populism: A Social History 1877-1898. New York: Hill and Wang, 1993.

Merriman, John M. The Dynamite Clube: How a Bombing in Fin-de-Siècle Paris Ignited the Age of Modern Terror. New Haven: Yale University Press, 2009.

Messer-Kruse, Timothy. The Trial of the Haymarket Anarchists: Terrorism and Justice in the Gilded Age. New York: Palgrave MacMillan, 2011.

Minkin, Helene. Storm in My Heart: Memories from the Widow of Johann Most. Edited by Tom Goyens and Translated by Alisa Braun. Oakland: AK Press, 2015.

Scott Miller, The President and the Assassin: McKinley, Terror, and Empire at the Dawn of The American Century. New York: Random House Trade Paperbacks, 2013.

Moran, Jessica. "The Firebrand and the Forging of a New Anarchism." The Anarchist Library,

https://theanarchistlibrary.org/library/jessica-moran-the-firebrand-and-the-forging-of-anew-anarchism-anarchist-communism-and-free-lov. 
Morgan, Murry. Puget's Sound: A Narrative of Early Tacoma and the Southern Sound. Seattle: University of Washington Press, 1979, 274-277.

Munk, Michael. The Portland Red Guide: Second Edition. Portland, Oregon: Ooligan Press, 2011.

Nelson, Bruce C. Beyond the Martyrs: A Social History of Chicago's Anarchists, 1870 1900. New Brunswick, Rutgers University Press, 1988.

O'Donnell, Terrence and Vaughan, Thomas. Portland: A Historical Sketch and Guide. Portland, Oregon Historical Society, 1976.

Pfaelzer, Jean. Driven Out: The Forgotten War Against Chinese Americans, New York: Random House, 2007.

Reichert, William O. Partisans of Freedom: A Study in American Anarchism. Bowling Green: Bowling Green University Popular Press, 1976.

Robbins, William G. Colony and Empire: The Capitalist Transformation of the American West/Lawrence: University Press of Kansas, 1994.

. Landscapes of Promise: The Oregon Story 1800-1940. Seattle: University of Washington Press, 1997.

Rocker, Rudolf. Anarchism and Anarcho-Syndicalism. 1938; reprint, London, Freedom Press, 1988.

Salerno, Salverto. Red November Black November: Culture and Community in the Industrial Workers of the World. Albany: State University of New York, 1989.

Sartwell, Crispin, ed. The Practical Anarchist: Writings of Josiah Warren. New York: Fordham University Press, 2001.

Schuster, Eunice Minette. "Native American Anarchism.” In Smith College Studies in History, XVII October, 1931 - July 1932. Northampton: Department of History of Smith College, 1931.

Schwantes, Carlos A. "Free Love and Free Speech on the Pacific Northwest Frontier: Proper Victorians vs. Portland's 'Filthy Firebrand.'” Oregon Historical Quarterly 82, no. 3 (Fall 1981): 271-93.

- "From Anti-Chinese Agitation to Reform Politics: The Legacy of the Knights of Labor in Washington and the Pacific Northwest." The Pacific Northwest Quarterly 88, no. 4 (Fall 1997): 174-84. 
_ . "Protest in a Promised Land: Unemployment, Disinheritance, and the Origins of Labor Militancy in the Pacific Northwest, 1885-1886." Western Historical Quarterly 13, no. 4 (October 1982): 373-90.

—. Radical Heritage. Seattle: University of Washington Press, 1979.

. "Washington State's Pioneer Labor-Reform Press: A Bibliographic Essay and Annotated Checklist." The Pacific Northwest Quarterly 71, no. 3 (July 1980): 11215.

. "Western Women in Coxey's Army in 1894." Arizona and the West 26, no. 1 (Spring 1894): 5-20.

Shelton, Tamara Venit. A squatter's Republic: Land and the Politics of Monopoly in California, 1850-1900. Berkeley: University of California Press, 2013.

Smith, Stephen Kent. "Research Note: Further Notes on Abraham Isaak, Mennonite Anarchist," Mennonite Quarterly Review 80, No. 1 (2006): 83.

Sonn, Richard D. Anarchism. New York: Twayne Publishers, 1992.

. Anarchism and Cultural Politics in Fin de Siècle France. Lincoln, University of Nebraska Press, 1989.

Stoll, Steven. Larding the Earth: Soil and Society in Nineteenth Century America. New York: Hill and Wang, 2002.

Tyler, Robert L. "I. W. W. in the Pacific N. W.: Rebels of the Woods." Oregon Historical Quarterly 55, no. 1 (March 1954): 3-44.

Voletz, Herman C. “Coxey's Army in Oregon, 1894." Oregon Historical Quarterly 65, no. 3 (September 1964): 263-295.

Wadland, Justin. Trying Home: The Rise and Fall of an Anarchist Utopia on Puget Sound. Corvallis: Oregon State University Press, 2014.

Weisbord, Albert. The Conquest of Power: Liberalism, Anarchism, Syndicalism, Socialism, Fascism, and Communism, Volume 1. New York: Covici-Friede, 1937.

Wrobel, David M. Promised Lands: Promotion, Memory, and the Creation of the American Wes.t Lawrence: University of Kansas Press, 2002.

Zimmer, Kenyon. Immigrants Against the State: Yiddish and Italian Anarchism in America. Urbana: University of Illinois Press, 2015. 